\title{
TROCANDO GALANTERIAS: A DIPLOMACIA DO COMÉRCIO DE ESCRAVOS, BRASIL-DAOMÉ, 1810-1812
}

\author{
Mariza de Carvalho Soares* \\ [...] pois eu cá estou defendendo muito as Costas de Sua Alteza, \\ e Vossa Alteza defenda as minhas costas. \\ Adandozan, rei do Daomé, 1810
}

$\mathrm{E}$

m 2006, coordenei o Projeto Acervo Digital Angola Brasil (PADAB), que digitalizou e permutou 108 códices do Arquivo Histórico Nacional de Angola (AHNA) com a coleção de documentos relativos à África do Instituto Histórico e Geográfico Brasileiro (IHGB), inventariados por Regina Wanderley. ${ }^{1}$ Desde 2010, coordeno o Projeto Africana do Museu Nacional, hoje financiado pela Fundação de Amparo a Pesquisa do Estado do Rio de Janeiro (Faperj), no qual estou fazendo o levantamento de todos os objetos africanos que compõem o acervo etnográfico do Museu Nacional, com vistas a um catálogo e também à reforma da sala de exposição. ${ }^{2} \mathrm{O}$ cruzamento desses dois projetos me levou a voltar à correspondência dos reis do Daomé, tema já explorado

\footnotetext{
* Professora da Universidade Federal Fluminense. marizacsoarees@ig.com.br.

1 O inventário da coleção do IHGB foi publicado em Regina M. Pereira Wanderley (coord.), "Inventário analítico da documentação colonial portuguesa na África, Ásia e Oceania integrante do acervo do Instituto Histórico e Geográfico Brasileiro", Revista do Instituto Histórico e Geográfico Brasileiro, v. 166, n. 427 (2005), pp. 27-570. O inventário dos códices do AHNA estão em fase final de revisão e devem ser disponibilizados pela equipe de pesquisa do IHGB, coordenada por Regina Wanderley, em 2014. A versão digital dos dois conjuntos de documentos (AHNA e IHGB) encontra-se disponível para consulta no IHGB.

2 Sob a coordenação geral do Prof. João Pacheco de Oliveira, chefe do Setor de Etnologia e Etnografia e curador das coleções etnográficas do Departamento de Antropologia do Museu Nacional. Agradeço a ele e à diretora do Museu Nacional, Profa. Claudia Rodrigues Ferreira de Carvalho, o incentivo para a implementação desse projeto.
} 
anteriormente por vários autores. Dentre os trabalhos mais importantes que analisam essas cartas estão os de J. F. de Almeida Prado, que, antes de Verger, escreveu "A Bahia e as suas relações com o Daomé", texto pioneiro mas pouco conhecido, publicado em seu livro $O$ Brasil e $o$ colonialismo europeu. O interesse de Verger pelas cartas dos monarcas africanos está presente em seu livro Fluxo e refluxo, especialmente no capítulo VII. Em seu livro Fragmentos setecentistas, a historiadora Silvia Lara apresenta uma primorosa análise dos "espetáculos negros", entre eles as embaixadas africanas no século XVIII. ${ }^{3}$

O rei Adandozan governou o Daomé entre 1796 e 1818. Sua carta a d. João, alvo do presente artigo, pertence ao acervo do IHGB, foi digitalizada pelo PADAB em 2006 e publicada por Nicolau Parés, na revista Afro-Ásia, em 2013. Em sua "Introdução" — como já apontado por Ana Lucia Araújo -, Parés atribui a John Thornton a localização dessa e de outras cartas no IHGB, confirmando ainda que Verger não tivera acesso a elas. Ele lista, transcreve e anota um total de quatorze cartas escritas pelos reis Agonglo, Adandozan e Guezo, entre 1790 e $1818 .{ }^{4}$ A carta de 1810 acompanha uma embaixada que chegou à Bahia em 1811. Entre outros assuntos, nela Adandozan informa a d. João que enviara por intermédio de seus embaixadores vários presentes, arrolados na carta.

Pierre Verger (depois de visita feita ao Museu Nacional em 1967) e Alberto da Costa e Silva já haviam escrito sobre tais presentes. Verger e Costa e Silva sabiam dos presentes, mas desconheciam a carta do IHGB. John Thornton foi o primeiro a citar a carta de 1810, mas não deu importância à lista de presentes. Ana Lucia Araújo foi a primeira a

\footnotetext{
3 J. F. de Almeida Prado, "A Bahia e as suas relações com o Daomé", in O Brasil e o colonialismo europeu, São Paulo: Nacional, 1956, pp. 114-22; Pierre Verger, Fluxo e refluxo do tráfico de escravos entre o Golfo do Benin e a Bahia de Todos os Santos dos séculos XVII a XIX, São Paulo: Corrupio, 1987; Silvia Hunold Lara, Fragmentos setecentistas: escravidão, cultura e poder na América portuguesa, São Paulo: Companhia das Letras, 2007, pp. 173-218.

4 Nicolau Parés publicou um conjunto de quatorze cartas de reis do Daomé: Agonglo (3), Adandozan (10) e Guezo (1). Dez delas já haviam sido publicadas anteriormente por Pierre Verger, quatro eram inéditas. As cartas inéditas de Adandozan, assim como a de Guezo pertencem ao acervo do IHGB. Ver Luís Nicolau Parés, "Cartas do Daomé: uma introdução" e "Cartas do Daomé (comentário e notas)", Afro-Ásia, n . 47 (2013), pp. 295-328 e 329-95. A carta de Adandozan de 1810 é a carta 13 , e passo aqui a indicá-la por esse número.
} 
cruzar as informações entre a carta do IHGB e os presentes incorporados ao acervo do Museu Nacional. ${ }^{5}$

Ao longo da pesquisa sobre a coleção de objetos africanos do Museu Nacional, pude verificar que, além dos objetos já identificados por Pierre Verger e Ana Lucia Araújo, existiam muitos outros, não mencionados por esses autores, mas que correspondem à lista fornecida por Adandozan em sua carta. Como historiadora, ter em mãos, de um lado, a carta e, de outro, os presentes me tem feito pensar - do ponto de vista arquivístico e museológico - sobre os caminhos seguidos por essas cartas e esses presentes até chegarem a seu destino: o IHGB e o Museu Nacional. ${ }^{6}$

No IHGB, a carta de 1810 de Adandozan integra o chamado "dossiê do Daomé", sob o número DL137,62. Dele consta um conjunto variado de cartas que inclui uma carta de d. João ao rei Agonglo, duas cartas do rei Adandozan a d. João, uma carta com assinatura irreconhecível por mim identificada como do rei de Ardra a d. João, uma carta do conde dos Arcos ao conde das Galveas (erradamente identificada no dossiê como de Galveas ao conde dos Arcos) e, por fim, uma carta do rei Guezo a d. João. As cinco primeiras formam um conjunto único e se referem todas à visita dos embaixadores dos reis do Daomé e Ardra à Bahia entre 1810 e 1812. A carta de Guezo, datada de 1818, foi juntada a esse conjunto posteriormente. As cinco primeiras cartas, ao que tudo indica, estavam em mãos do conde das Galveas. Tal hipótese se baseia no fato de que, em sua carta, o conde dos Arcos diz a Galveas que es-

\footnotetext{
5 Ver Pierre Verger, Os libertos: sete caminhos na liberdade de escravos na Bahia do século XIX, Salvador/São Paulo: Corrupio, 1992 e, mais especificamente sobre o tema, "Uma rainha africana mãe de santo em São Luís", Revista da USP, v. 6 (1990), pp. 151-8; Alberto da Costa e Silva, "Uma visão brasileira da escultura tradicional africana", in Peter Junge (org.), Arte da África (Rio de Janeiro: Centro Cultural Banco do Brasil, 2004), pp. 60-1; John K. Thornton, "Dahomey in the World: Dahomean Rulers and European Demands, 1726-1894", <http://www. wcfia.harvard.edu/sites/default/files/Dahomey\%20in\%20the\%20World\%20-\%20Thornton.pdf>, acessado em 12.07.2013; Ana Lucia Araújo,"Dahomey, Portugal and Bahia: King Adandozan and the Atlantic Slave Trade", Slavery \& Abolition, v. 33, n. 1 (2012), pp. 1-19.

6 Desde 2010, coordeno o projeto Africana do Museu Nacional, hoje financiado pela Faperj. Para os primeiros resultados do estudo da coleção, ver Mariza de Carvalho Soares e Rachel Corrêa Lima, "A Africana do Museu Nacional: história e museologia", in Camilla Agostini (org.), Objetos da escravidão: abordagens sobre a cultura material da escravidão e seu legado (Rio de Janeiro: 7Letras, 2013), p. 337-59.
} 
tava enviando a correspondência dos reis do Daomé e Ardra destinadas à apreciação de d. João. Na ocasião, Galveas era ministro, logo depois adoeceu, vindo a falecer em 1814. Ao que tudo indica, as cartas ficaram entre seus papéis. Em data posterior, o acervo de Galveas deu entrada no IHGB e, acredito, com ele, as referidas cartas. Infelizmente, não encontrei até agora no IHGB nem o registro de entrada das cartas, nem da própria documentação do conde das Galveas. Fato é que o acervo de Galveas está no IHGB e que o "dossiê do Daomé" faz parte dele.7

Este texto se baseia em um conjunto de cartas que circularam entre o Rio de Janeiro e a Bahia entre 1810 e 1812, todas envolvendo as negociações sobre a presença das embaixadas dos reis do Daomé e Ardra na Bahia: uma carta de Adandozan (1810), uma carta de d. João (1796), uma carta do rei de Ardra (supostamente 1810) e uma carta do conde dos Arcos (1811), todas do dossiê do IHGB. Recorro ainda a outras duas cartas do conde das Galveas ao conde dos Arcos (1811 e 1812), encontradas na Biblioteca Nacional. Com exceção da carta de Adandozan, todas as demais são inéditas e estão transcritas em anexo a este artigo. ${ }^{8}$

Quanto à coleção de presentes, ainda está em processo de identificação. Verger diz ter visto o trono, uma bandeira e associa ambos ao "presente" enviado por Adandozan em sua embaixada de 1810. A fonte da informação é outra carta que não informa que presente seria esse, fazendo Verger supor que fosse o trono e a bandeira. Por isso os demais objetos daomeanos por ele encontrados no acervo do Museu Nacional ("provavelmente três cetros" e "sandálias bordadas") não foram por ele identificados como parte do presente enviado por Adandozan a d. João em 1810. ${ }^{9}$ Além dos objetos mencionados por Verger e Costa e Silva (cita apenas o trono e a bandeira), Ana Lucia Araújo identificou também um estojo para cachimbo que estava na exposição permanente do Museu

O "dossiê sobre o Reino do Daomé” (IHGB, DL137,62) aparece sob o número 616 no inventário analítico. Ver Wanderley (coord.), "Inventário analítico".

8 Rei Adandozan a d. João (Parés, "Cartas do Daomé", carta 13); d. João ao rei Agonglo (IHGB, DL 137,62, Anexo, carta 1), rei de Ardra a d. João (IHGB, DL 137,62, Anexo, carta 2); conde dos Arcos ao conde das Galveas (IHGB, DL 137,62, Anexo, carta 3); primeira carta do conde das Galveas ao conde dos Arcos (BN-RJ, II-33-29-23, Anexo, carta 4); e segunda carta do conde das Galveas ao conde dos Arcos, (BN-RJ, II-33,29,127, Anexo, carta 5)

9 Ver Verger, "Uma rainha africana". 
Nacional, por ocasião de sua visita em $2005 .{ }^{10}$ Além dos presentes, já foi possível encontrar, na reserva técnica, quatro bengalas, dois panos, abanos, um par de sandálias, bolsas e outros objetos que combinam com a lista dos presentes. Ao que tudo indica, todos eles compuseram a coleção inaugural do Museu Real em 1818. Não apenas as cartas mas também os presentes chegaram ao Rio de Janeiro e, de algum modo, foram preservados até serem enviados a instituições adequadas à sua guarda. Da lista feita na carta, vários presentes não foram encontrados, entre eles um anel de ouro e outro de prata. Tudo indica que os presentes foram enviados pelo conde dos Arcos ao conde das Galveas, junto com as cartas. ${ }^{11}$

Seguindo o percurso das cartas e dos presentes, de como a burocracia régia lidou com eles e à luz da literatura já produzida sobre as embaixadas africanas, me dei conta da importância da diplomacia de amizade entre os reis de Portugal e do Daomé. O presente artigo destaca essa diplomacia da amizade que, nos anos de 1810-1812, marcou não apenas as relações entre Portugal/Brasil e Inglaterra, mas também entre Portugal/Brasil e os reinos africanos exportadores de escravos, mesmo depois da assinatura do Tratado de Aliança e Amizade com a Inglaterra (1810), que previa a abolição do tráfico de escravos africanos pelos portugueses.

Essa diplomacia entre reis, mais que entre estados ou nações, já existia por ocasião da embaixada enviada pelo rei Tegbessu, do Daomé, ao rei de Portugal, d. José I, em 1750, por meio do conde de Athouguia, então vice-rei do Brasil, residente na Bahia. Uma descrição da passagem dessa embaixada pela cidade do Salvador foi deixada por José Freire Montarroio Mascarenhas publicada em Lisboa, em 1751. Nessa memó-

\footnotetext{
10 Araújo, "Dahomey, Portugal and Bahia", pp. 14-5.

11 Sobre o trajeto dos presentes até o museu existem duas possibilidades mais viáveis. A primeira é que os presentes permaneceram como "curiosidade" entre os pertences de d. João e foram enviados ao museu por ocasião de sua criação. Para essa hipótese o problema é que tais objetos não constam da lista de objetos doados por d. João ao Museu em 1818. A outra possiblidade, que parece mais plausível, é que o próprio conde das Galveas tenha enviado os presentes ao chamado Gabinete de Curiosidades, cujo acervo integrou a coleção inaugural do Museu Real. Sobre os objetos africanos na coleção inaugural do Museu Nacional, ver Mariza de Carvalho Soares. "Collectionism and Colonialism: The Africana Collection at Brazil's National Museum (Rio de Janeiro)" in Ana Lucia Araujo (ed.) African Heritage and Memory of Slavery in Brazil and the South Atlantic World (Amherst/New York: Cambria Press, no prelo).
} 
ria, analisada por Silvia Lara, o autor narra a audiência concedida pelo vice-rei aos embaixadores daomeanos:

[...] tirou do seio uma carta, e a entregou ao conde, recomendando-lhe o segredo dela; e continuou dizendo: receba Vossa Excelência [conde de Athouguia] esta representação da parte daquele grande Monarca [rei Tegbessu], que o elegeu para ocupar este lugar. O presente vem dentro do pacote que mandarei entregar logo a Vossa Excelência, a cujos pés ponho, na presença de todo este auditório, a minha pessoa. Tenho satisfeito ao que o meu Soberano me encarregou. O segredo, que Vossa Excelência verá na sua carta, não será público, bem manifesto, sem expressa ordem do seu Soberano Monarca [rei d. José], e do meu grande Rei de Angome. Despediu-se com estas últimas palavras, e com as mesmas cortesias. ${ }^{12}$ (grifos meus)

Os referidos presentes eram "dois caixões, chapeados de ferro, com as fechaduras lavradas", um deles para d. José, e outro para o vice-rei, "com as quatro negrinhas". Mascarenhas esclarece que "não se divulgou nunca bem o que a carta continha, nem o que os caixões encerravam", apenas que "correu em Lisboa que chegara da Bahia um dos caixões para Sua Majestade [rei d. José], e três negrinhas". ${ }^{13}$ Difícil avaliar o grau de segredo dessas cartas, mas o certo é que a embaixada foi recebida na Bahia, as cartas e presentes enviados a Portugal; e que alguém se preocupou em dela deixar uma memória. Como se verá adiante, os presentes enviados pelo rei de Portugal ao rei Tegbessu também chegaram a seu destino e ficaram bem guardados no Palácio de Abomé, onde foram encontrados, anos mais tarde, pelo rei Adandozan quando assumiu o lugar de seu pai, rei Agonglo.

O mais vasto levantamento das cartas trocadas entre os soberanos

\footnotetext{
12 José Freire Montarroio Mascarenhas, Relaçam da Embayxada que o Poderosso Rey de Angome Kiay Chiri Broncom, Senhor dos dilatadíssimos Sertões de Guiné mandou ao Illustrissimo e Excellentissimo Senhor D. Luiz Peregrino de Ataide, Conde de Atouguia... Vice-Rey do Estado do Brasil: Pedindo a amizade, e aliança do muito At; e Poderoso Rey de Portugal nosso senhor, Lisboa, Na Officina de Francisco da Silva, 1751, p. 10-1. Para uma análise dessa embaixada, ver Silvia Hunold Lara, Fragmentos setecentistas: escravidão, cultura e poder na América portuguesa, São Paulo: Companhia das Letras, 2007; Ana Lucia Araújo, "Dahomey, Portugal and Bahia".

13 Mascarenhas, Relaçam da Embayxada, p. 11. Segundo Pierre Verger, uma das meninas ficou doente, e só três foram enviadas a Portugal. Pierre Verger, Fluxo e refluxo, p. 263.
} 
de Portugal e do Daomé foi realizado por Pierre Verger no Arquivo Histórico Ultramarino (AHU), em Lisboa, no Arquivo Público do Estado da Bahia (APEB), em Salvador, e na Biblioteca Nacional (BN-RJ), no Rio de Janeiro. Segundo esse autor, são ao todo oito visitas: quatro de enviados dos reis do Daomé, uma do rei de Ardra e outras três dos reis de Onim. Segundo Verger, as cartas mostram a determinação desses monarcas africanos em "manter as relações comerciais estreitas entre seus países e a Bahia". O Daomé enviou embaixadas a Lisboa em 1750 (rei Tegbessu), 1795 (rei Agonglo) e 1805 (rei Adandozan). A embaixada de 1810, destinada ao Rio de Janeiro, foi detida na Bahia. ${ }^{14}$ Falecido d. José, é já d. João quem, em nome de sua mãe, d. Maria, negocia e se corresponde com Agonglo em 1795 e, depois, com Adandozan em 1805 e 1811. D. João é, portanto, a presença mais constante nessa série de negociações diplomáticas.

A carta de d. João datada de 1796, transcrita em anexo, responde a uma carta escrita pelo rei Agonglo em 1795. A carta é escrita no Palácio de Queluz e dirigida ao "Nobre e Honrado Rey de Dagome", em 6 de janeiro de 1796, e assinada "Príncipe". Começa explicando que escreve em nome de d. Maria, sua mãe, e que recebera das mãos dos embaixadores a carta datada de 20 de março de 1795, "com aquele apreço, que sempre fizeram os Senhores Reis Meus predecessores, desejando estreitar cada vez mais os vínculos de Amizade, e boa união". Em seguida, trata do comportamento dos administradores do forte português do porto de Ajudá, e termina dizendo que

[...] ao novo Diretor [do forte de Ajudá] recomendo o maior zelo em todos os ditos trabalhos, para que a dita Fortaleza e as Vossas Terras fiquem na devida segurança, e podeis ficar certo que o Diretor que transgrediu as Minhas Ordens, e que não teve atenção com os Vossos Desejos será punido exemplarmente segundo as Leis, logo que se transportar a estes Reinos. ${ }^{15}$

\footnotetext{
14 É a seguinte a cronologia dos reis do Daomé no período abrangido pelo texto: Tegbessu (17321774); Kpengla (1774-1789); Agonglo (1789-1797); e Adandozan (1797-1818). O capítulo VII do livro de Pierre Verger (Embaixadas dos reis do Daomé e dos países vizinhos para a Bahia e Portugal) trata especificamente do tema. Verger, Fluxo e refluxo, pp. 257-84.

15 Anexo, carta 1.
} 
Por fim, diz ter encontrado, anexo à carta, um papel com vários pedidos: um bergantim (tipo de embarcação) "pronto de tudo para a guarda desse Porto [de Ajudá]", um homem que "soubesse bem ler, e escrever", "um navio, cuja carga fosse de sedas boas de ouro e prata em obra, e tudo os mais que pertence a um Rei, e finalmente quarenta peças de Bronze, e Ferro [canhões] bastantemente reforçadas para guarnecer a Vossa Terra [o território português de Ajudá, em torno do forte]”. Na carta, d. João informa que não atendera a esses pedidos, mas que "a tudo isto procurarei satisfazer quando me seja possível fazê-lo"; e se despede com votos de "Fiel Amizade".

A carta de d. João (transcrita em anexo), enviada ao então rei Agonglo, em 1796, é a resposta à carta de Agonglo enviada a d. José em 20 de março de $1795 .{ }^{16}$ Uma cópia dessa carta foi encontrada pelo conde dos Arcos, então governador da Bahia (1810-1818), anexada às demais e mandada para o conde das Galveas no Rio de Janeiro, em 1811. Essa carta foi anexada, segundo ele, por tratar do mesmo tema (comércio de escravos) e servir de motivo para as perguntas que faz, em sua própria carta, ao conde das Galveas. ${ }^{17}$ Todas essas cartas são então encaminhadas a Galveas junto com uma carta do próprio conde dos Arcos, escrita na Bahia em 7 de maio de 1811. Esse é o conjunto reunido inicialmente no "dossiê" do IHGB. Em sua carta, o governador pergunta ao conselheiro de Estado como proceder sobre as negociações do comércio de escravos junto aos dois embaixadores africanos, depois da assinatura do Tratado de Aliança e Amizade, no ano anterior. Ao final do artigo, agrego à análise dessas cartas duas outras, do conde das Galveas, encontradas na documentação relativa à Bahia da Biblioteca Nacional (também transcritas em anexo). ${ }^{18}$

16 Verger transcreveu um longo trecho de uma outra carta de 1795, depositada na Biblioteca Nacional-RJ (ver $A B N$, v. 68, 1949). Ver Parés, "Cartas do Daomé", carta 2, pp. 333-4.

17 Acredito que o costume de colocar o nome do remetente e do destinatário ao fim da carta induziu a um equívoco na identificação da carta no inventário do IHGB, onde consta ter sido ela escrita por Galveas e destinada ao conde dos Arcos. Na verdade, a carta foi escrita na Bahia pelo conde dos Arcos e dirigida ao conde das Galveas, então conselheiro de Estado no Rio de Janeiro. Ver Anexo, carta 3. Em momento posterior, foi juntada ao dossiê uma carta de Guezo, rei do Daomé, que tomou o trono de Adandozan e reinou de 1818 a 1858.

$18 \operatorname{Ver} A B N$, v. 68, 1011. Coleção Bahia: ofício do conde de Galveas, ao conde dos Arcos, governador da Bahia, sobre propostas comerciais trazidas pelas embaixadas do Dahomey que se encontram nessa capitania. Rio de Janeiro, 02.08.1811. I doc. (3 fs.), II-33,29,23 (1811); e $A B N$, v. 68, 1042. Coleção Bahia: ofício do conde das Galveas ao conde dos Arcos, governador da Bahia, sobre os embaixadores pretos que se encontram nessa cidade, Rio de Janeiro, 21.03.1812. 1 doc. (1 fl.), II-33,29,127 (1812). Ver Anexo, cartas 4 e 5. 
Por fim, o último motivo para esse conjunto alargado de cartas - e o que na verdade determina o rumo deste artigo - é o fato de que, tomadas isoladamente ou segmentadas em cartas africanas de um lado e correspondência da burocracia régia de outro, elas perdem sua intrincada conexão e a dimensão diplomática que possuem. Juntas permitem uma abordagem diferenciada, fundamental para a apreensão do contexto no qual foram escritas e circularam. ${ }^{19}$

A análise da carta enviada por Adandozan a d. João em 1810 permite acompanhar a atuação dos quatro personagens em jogo: o próprio Adandozan, que dita a carta; d. João, a quem a carta é dirigida; o conde dos Arcos, governador da Bahia que recebe os embaixadores e escreve ao conde das Galveas; e o conde das Galveas, do Conselho de Estado, ministro secretário de Estado dos Negócios da Marinha, Domínios Ultramarinos, responsável pela diplomacia e pelos negócios aos quais a embaixada se destina, sediado no Rio de Janeiro, junto a d. João.

A carta de Adandozan a d. João, datada de 9 de outubro de 1810, é escrita na sequência dos tratados de Comércio e Navegação e Aliança e Amizade, este último assinado em 19 de fevereiro de 1810, no Brasil, e em 18 de junho, na Grã-Bretanha. Tais tratados, supostamente, selam um pacto entre Inglaterra e Portugal em prol da extinção do comércio atlântico de escravos..$^{20} \mathrm{O}$ artigo 10 da ratificação do Tratado de Aliança e Amizade diz:

Sua Alteza real o Príncipe de Portugal, estando plenamente convencido da injustiça e má política do comércio de escravos, e da grande desvantagem que nasce da necessidade de introduzir e continuamente renovar uma estranha e factícia população para entreter o trabalho e indústria nos Seus domínios do Sul da América, tem resolvido de cooperar com Sua Majestade Britânica na causa da humanidade e justiça, adotando os mais eficazes meios para conseguir em toda a extensão dos Seus domínios uma gradual abolição do comércio de escravos. E movido por este princípio, Sua Alteza Real e Príncipe Regente de Portugal Se obriga a que aos Seus vassalos não será permitido continuar o comércio

\footnotetext{
19 Parés, "Cartas do Daomé", cartas 12 e 13, pp. 360-77 e 377-92, respectivamente.

20 Leslie Bethell, A abolição do comércio brasileiro de escravos: a Grã-Bretanha, o Brasil e a questão do comércio de escravos, 1807-1869, Brasília: Senado Federal, 2002.
} 
de escravos em outra alguma parte da Costa da África, que não pertença atualmente aos domínios de Sua Alteza Real, aos quais neste comércio foi já descontinuado e abandonado pelas Potências e Estados da Europa que antigamente ali comerciavam; reservando contudo para os Seus próprios vassalos o direito de comprar e negociar em escravos nos domínios africanos da Coroa de Portugal. Deve porém ficar distintamente entendido que as estipulações do presente Artigo não serão consideradas como invalidando ou afetando de modo algum os direitos da Coroa de Portugal aos territórios de Cabinda e Molembo, os quais direitos foram em outro tempo disputados pelo Governo da França, nem como limitando ou restringindo o comércio de Ajudá e outros portos da África [situados sobre a costa comumente chamada na língua Portuguesa de Costa da Mina], e que pertencem, ou a que tem pretensões a Coroa de Portugal, estando Sua Alteza Real o Príncipe Regente de Portugal resolvido a não resignar, nem deixar perder as Suas Justas e legítimas pretensões aos mesmos, nem os direitos de Seus Vassalos de negociar com estes lugares, exatamente pela mesma maneira que eles até aqui o praticavam. ${ }^{21}$

Quem sabe preocupados com o novo tratado, os reis de Ardra e Daomé enviam, como já era de costume, novas embaixadas ao Brasil. Em dezembro de 1810, chega à Bahia a embaixada do rei de Ardra (ou Porto Novo, nome de seu entreposto de comércio atlântico) e, em janeiro de 1811, chega a embaixada do rei do Daomé, ambos concorrentes entre si e interessados em garantir o comércio de escravos com o Brasil.

Em outubro de 1810, quando entrega a seus embaixadores a carta endereçada a d. João, Adandozan possivelmente já tinha conhecimento da formalização da aliança entre Portugal e Inglaterra. Já tinha também conhecimento da ordem de d. João de não permitir que suas embaixadas passassem de Salvador a Lisboa, fazendo supor que seriam também impedidas de ir ao Rio de Janeiro. Não à toa, na carta, demonstra preocupação com o sucesso de sua embaixada. Existia uma proibição emitida após a embaixada enviada por Adandozan em 1805, com o intuito de evitar que os embaixadores africanos fossem a Lisboa, devendo ficar retidos na Bahia. Diz a ordem:

\footnotetext{
21 Artigo X da ratificação do Tratado de Aliança e Amizade, José Ferreira Borges de Castro, Colleção dos tratados, convenções, contratos e actos públicos... tomo IV, Lisboa: Imprensa Nacional, 1857 , p. 408.
} 
Finalmente ordena S. A. R. que, se o Rey de Dagomé, ou outro potentado da Costa de África, quiser mandar por essa capitania emissários a esta Corte, Vossa Senhoria dê primeiro parte do objeto da sua missão, remetendo as cartas, que eles trouxerem, e todas as informações necessárias, e os detenha aí até receber novas Ordens, sendo conveniente evitar assim a despesa de tais missões, inúteis, como se prova pela experiência da que veio a Lisboa em 1795, antecedente à atual. D. Gde. a V. [Sa.] Palácio de Queluz em 30 de Julho de 1805.22

Era já uma atitude bem diferente da adotada por d. João em 1796, quando escreve ao rei Agonglo dando conta da embaixada de 1795 mencionada na ordem transcrita acima. Ao se dirigir a Agonglo em 1796, sua fala é bem diferente da que apresenta na ordem de 1805. Na carta de 1796, ele mostra não apenas o comportamento dos embaixadores mas também o custo dessa permanência como parte da diplomacia da época:

Os Vossos Embaixadores se comportaram nesta Corte com toda decência, e honra, próprias do seu caráter, dando-lhe todas as provas do seu zelo pelo Vosso Serviço, e fazendo-se dignos da Minha Real Atenção, e portanto merecedores da Vossa particular Benevolência na qual os recomendo. Eu lhe mandei assistir com tudo aquilo de que necessitavam para a sua decente subsistência, na forma que vos será constante pela conta que vos transmito, e igualmente lhes mandei satisfazer a sua passagem até a Bahia; ordenando ao governador daquele Estado, que os assista igualmente com todo o necessário até chegarem aos Vossos Domínios. ${ }^{23}$

A proibição de 1805 está, portanto, ligada a uma nova diretriz, para evitar os gastos excessivos que tais embaixadas custavam aos cofres portugueses. A partir de 1807, à contenção de despesas se acresce a nova conjuntura internacional e a ordem de 1805 , ainda em vigor, precisa ser interpretada à luz dos novos acontecimentos. Na sequência da abolição do comércio atlântico de escravos pelos ingleses, em 1807, os novos tratados podiam trazer desdobramentos negativos para o comércio do Daomé com o Brasil, e renegociações se faziam urgentes. Havia que

22 BN-RJ II- 34, 5, 4, "Visconde de Anadia ao [governador da Bahia], Palácio de Queluz, 30/07/1805". Agradeço a Nicolau Parés o alerta sobre essa ordem, por ele citada em Parés, “Cartas do Daomé", p. 384, nota 272, que me passara desapercebida.

23 Anexo, carta 1. 
continuar restringindo gastos, mas, em 1811, esse era um bom motivo, posto que já utilizado anteriormente, para manter os embaixadores do comércio de escravos longe da Corte.

Seguindo os costumes, os embaixadores de Adandozan devem ter deixado Abomé, capital do reino, em grande pompa, levando consigo as cartas e os presentes, para embarcar no porto de Ajudá com destino ao Rio de Janeiro, fazendo escala na Bahia. ${ }^{24}$ Chegando à Bahia, o embaixador de Adandozan foi ali detido pelo governador, o conde dos Arcos, que não permitiu seu reembarque para o Rio de Janeiro e negociou com ele a remessa das cartas e presentes a d. João, com a condição de que retornasse ao Daomé. ${ }^{25}$ A mesma estratégia já tinha sido adotada com o rei de Ardra, cuja embaixada já se encontrava na cidade quando o embaixador do Daomé desembarcou.

A atitude do conde dos Arcos segue a orientação da proibição de 1805 , mas, na conjuntura de 1810 , certamente vem cercada de novos motivos já então associados ao novo quadro internacional. Por meio de uma ordem régia de 6 de fevereiro de 1811, já com as duas embaixadas na cidade da Bahia, d. João reitera a proibição de 1805, ordenando que as embaixadas permaneçam na Bahia e de lá retornem a seus reinos. Ainda não localizei esta ordem, mas dela dá notícias a carta de d. João ao rei de Ardra, na mesma ocasião. Nessa carta, d. João expõe outros motivos para evitar a ida dos embaixadores ao Rio de Janeiro. É importante notar que a embaixada do rei de Ardra desembarcara na Bahia em dezembro de 1810 e que a carta de d. João foi enviada em fevereiro de 1811, na mesma data da ordem régia, visando a impedir que o conde dos Arcos embarcasse as embaixadas de Ardra e Daomé para o Rio de Janeiro. Em vez de repetir o argumento do custo de tais embaixadas, como fizera em 1805, d. João alegou querer "evitar a estes mensageiros

\footnotetext{
24 Suponho que a embaixada tenha embarcado em Ajudá, o principal porto de comércio na costa sob o domínio do Daomé. Em suas cartas Adandozan faz longas referências a esse porto e à administração local portuguesa. Sobre o tema, ver Verger, Fluxo e refluxo; Robin Law, Ouidah: the Social History of a West African Slaving 'Port' 1727-1892, Athens: Ohio University Press; Oxford: James Currey, 2004.

25 Contrariando a hipótese de Verger de que Guezo deu a Dossuyévo (grafia de Verger) o título de Chachá Ajinacu e o enviou ao Brasil em busca de sua mãe, Parés sugere ter sido Dossuyovo (grafia de Parés) o embaixador da embaixada enviada por Adandozan ao Brasil em 1810. Ver Parés, "Cartas do Daomé: uma introdução", p. 325.
} 
a fatiga da segunda parte da viagem", acrescentando "a dificuldade em achar embarcações diretas para a volta" dos embaixadores porque "a navegação para a Costa da Mina fazia-se ordinariamente a partir do porto da Bahia". E termina dizendo que "todas estas demoras eram nocivas à boa e rápida marcha das negociações". ${ }^{26}$

São, sem dúvidas, razões mais diplomáticas do que se recusar a pagar os custos das visitas, mostrando, mais uma vez, sua preocupação com as boas relações e o tratamento adequado às embaixadas. $\mathrm{O}$ argumento tem nitidamente o intuito de acalmar os ânimos do monarca de Ardra. As desculpas são injustificadas, já que todos tinham conhecimento das dificuldades apontadas e contavam com elas. Por outro lado, em troca do rápido retorno, d. João propõe uma "boa e rápida marcha das negociações", apontando para um acordo à distância. De um lado, d. João assina tratados com a Inglaterra e, de outro, renova sua diplomacia com os monarcas africanos, mantendo sua opção pelo prolongamento do comércio de escravos.

A chegada das embaixadas de Ardra e Daomé a Salvador coloca a questão do comércio atlântico de escravos no coração das relações diplomáticas entre Portugal e Inglaterra de um lado, e entre Portugal e os reinos africanos de outro. O modo como d. João trata cada uma das partes envolvidas e como as práticas comerciais concomitantes a essa diplomacia são alvo de divergências no interior da burocracia régia portuguesa é um ponto que a correspondência aqui analisada permite explorar. Se, em 1795, a questão da extinção do comércio atlântico fora um tema longínquo, em 1810-1812, ele está no centro do debate imposto pelas novas relações entre Portugal e Inglaterra. Para melhor entender esse contexto, passo a investigar o conjunto das cartas.

Em sua carta, o conde dos Arcos informa ter convencido os embaixadores a permanecer na Bahia, passando a ele a responsabilidade de remeter suas cartas a d. João. ${ }^{27} \mathrm{O}$ conde dos Arcos dá seu próprio tom aos

\footnotetext{
26 Esse trecho da carta foi extraído do livro de Verger, pois não tive acesso à íntegra do documento. Verger, Fluxo e refluxo, p. 280.

27 Entre as cartas supostamente enviadas estavam as cartas 12 e 13, publicadas pela Afro-Ásia, e ainda a carta do rei de Ardra (Anexo, carta 2).
} 
acontecimentos. Em primeiro lugar, trata as cartas de Adandozan como "escritos abomináveis" (provavelmente se referindo à descrição das guerras e do sacrifício dos prisioneiros), deixando claro seu desagrado em relação a esse monarca e às relações diplomáticas de Portugal com os reinos africanos de um modo geral. Faz ainda uma breve menção a "montões de objetos frívolos", provavelmente os presentes descritos por Adandozan em sua carta. Apesar da repulsa ao conteúdo das cartas e à qualidade dos presentes, tudo chega ao Rio de Janeiro. ${ }^{28}$

A questão colocada pelo conde dos Arcos ao conde das Galveas é como pode d. João assinar um tratado com a Inglaterra e continuar o comércio de escravos com a África. O governador começa informando que recebera a ordem régia de 6 de fevereiro de 1811 e que mandara aviso aos "embaixadores dos reis de Ardra ou Porto Novo e Daomé" para que tratassem com ele "sobre suas respectivas Missões". Em seguida, informa que, anexa à sua carta, estava, em primeiro lugar, a já referida carta enviada pelo rei de Ardra e, em segundo, um "saco" de cartas do rei do Daomé. ${ }^{29}$ Sobre o embaixador do rei do Daomé, explica que ele "insistia em querer ir a sua Corte por isso que assim era Ordem do seu Rei" e que foi preciso dizer-lhe "firme, e secamente que as Ordens de Sua Alteza Real eram as que regiam neste caso". Sobre as relações com os reinos africanos, o conde deixa claro ser contrário à continuidade desse contato amistoso, referindo-se à carta de d. João que encontrara e anexara às demais. Diz explicitamente não concordar com d. João em sua atitude de "temporizar com estes Potentados como se mostra na cópia junta da carta assinada pelo Régio Punho datada aos seis de janeiro de 1796". ${ }^{30}$ Tal questionamento logicamente não se restringia à carta de 1796, mas à continuidade da postura do regente nas negociações de 1811 .

Continuando sua carta, que identifica como um "parecer", o conde pede que se lhe "aclareie a inteligência do Artigo Décimo do Tratado de Aliança de 19 de fevereiro de 1810 " e diz ser "indispensável para que eu

\footnotetext{
28 As cartas chegaram ao Palácio do Rio de Janeiro pelas mãos do conde das Galveas que as recebera do conde dos Arcos. Os presentes não são mencionados, mas devem ter vindo junto com as cartas. Sobre a coleção de objetos africanos, ver Soares e Lima, "A Africana do Museu Nacional".

29 Aí incluídas Parés, "Cartas do Daomé", cartas 12 e 13.

30 Anexo, carta 3.
} 
[conde dos Arcos] fale sisudamente sobre este negócio estar certo". ${ }^{31} \mathrm{Ou}$ seja, o conde reconhece em d. João uma simpatia pelos soberanos do Daomé e por suas pretensões, questionando essa atitude face à assinatura do tratado de 1810 com a Inglaterra. Em seguida, expõe, mais uma vez, sua dúvida:

[...] se a Vontade de Sua Alteza Real é adotar os mais eficazes meios para conseguir em toda a extensão dos seus domínios uma gradual abolição do Comércio de Escravos, ou que as estipulações daquele mesmo artigo não sejam consideradas como limitando ou restringindo o Comércio de Ajudá. ${ }^{32}$

A questão é, portanto, saber se, como governador da Bahia, deveria dar continuidade ao comércio de escravos com o Daomé através do porto de Ajudá, ou se o tratado traria mudanças e novas orientações. $\mathrm{Na}$ verdade, pelo tom da carta, espera por mudanças e pela progressiva redução daquele comércio.

O conde dos Arcos governou a Bahia de 1810 a 1818. Em várias ocasiões, argumentou sobre a liberdade dos escravos e as condições do tráfico. ${ }^{33}$ Segundo o historiador João José Reis, ele tinha "inclinação iluminista". ${ }^{34}$ Quanto aos embaixadores africanos, homens livres e envolvidos em relações diplomáticas, teve para com eles uma atitude de representante régio: hospedou as embaixadas, dando-lhes o prestígio esperado. ${ }^{35}$

A atitude do conde dos Arcos, coerente com sua visão da escravidão e do comércio de escravos, traz à tona as diferentes interpretações

31 Anexo, carta 3.

32 Anexo, carta 3.

33 Sobre o conde dos Arcos, ver João José Reis, Rebelião escrava no Brasil: a história do Levante dos Malês em 1835, São Paulo: Companhia das Letras, 2003. pp. 81-93. Sobre a atuação do conde dos Arcos junto às embaixadas na Bahia, ver Verger, Fluxo e refluxo, pp. 279-83.

34 Reis, Rebelião escrava no Brasil, p. 81. Sua formação iluminista pode ser identificada em um trecho da carta onde diz que qualquer julgamento deve ser precedido por um conhecimento da matéria, no caso, dos reinos em discussão: "que primeiro que tudo se trate de obter os conhecimentos sólidos, e necessários para entrar com claridade nesta matéria, mandando pessoas de inteligência, e probidade a os Portos de ambos os Potentados encarregados de transmitir ao Governo com a maior exatidão todas as ideias sobre a História, Topografia, interesses econômicos, e parte Militar dos países sem as quais confesso a Vossa Excelência que não me atraem a falar na Augusta Presença de Sua Alteza Real sobre este negócio...”. Anexo, carta 3.

35 Em conversa informal, João Reis me relatou que o conde dos Arcos apadrinhou o embaixador do rei de Ardra que foi batizado, junto com seu secretário, durante a estadia da embaixada na cidade da Bahia. Repetia o conde o ato de d. João que, em 1796, batizara o embaixador do reino do Daomé com o nome cristão de João Carlos de Bragança. Ver Parés, “Cartas do Daomé”, carta 2, p. 333, nota 19. 
do tratado, segundo as conveniências de cada grupo comercial, os interesses das diferentes esferas da burocracia régia e as preferências do próprio monarca. Essa polêmica é fundamental para entender a atitude tanto de d. João quanto de Adandozan. Embora talvez Adandozan não tenha clareza dos termos da aproximação entre Portugal e Inglaterra, sabe da importância do porto de Ajudá, o único da Costa da Mina onde Portugal tem, sem ferir as pretensões inglesas, condições de continuar a comprar escravos por ter ali presença territorial inquestionável desde a instalação de um forte, no século XVIII. ${ }^{36}$ Não à toa, nas cartas reunidas no tal "saco", Adandozan faz longas descrições dos problemas por ele enfrentados junto à administração portuguesa do forte de Ajudá. Por outro lado, Adandozan sabe que existem pressões contrárias e que os novos tratados comerciais ameaçam esse comércio, como bem mostra, de um lado, a reação do conde dos Arcos e, de outro, as pretensões do rei de Ardra.

A atitude de d. João no sentido de impedir o deslocamento das embaixadas para o Rio de Janeiro, explicitada na ordem régia de 6 de fevereiro de 1811, longe de indicar sua pretensão em romper com a ancestral aliança, reforça a decisão de 1805 de impedir a viagem de embaixadores africanos à Corte, mas tenta também evitar entrar em conflito com os reis africanos. Naquele momento, a proibição resolvia dois problemas: custos da ida ao Rio de Janeiro e os embaraços dessa visita aos olhos dos aliados da Inglaterra. Evitava, assim, expor suas alianças em plena Corte, adiando a reverberação do debate sobre a legitimidade do comércio de escravos. Não à toa, sua ordem régia impede o deslocamento das embaixadas para o Rio de Janeiro, mas as mantém na cidade do Salvador por mais de um ano, a custos que não devem ter sido desprezíveis.

É importante aqui deixar claro que a preocupação de d. João não são os reis e sim Portugal, o Brasil e ele próprio. Sua ordem desagradou tanto ao rei de Ardra quanto ao rei do Daomé. O rei de Ardra não

\footnotetext{
36 Segundo Costa e Silva, por esse motivo Felix de Souza deslocou seus negócios para Ajudá, de onde passou a embarcar seus escravos para a Bahia. Em 1812, 45 embarcações da Bahia aportaram em Ajudá. Ver Alberto da Costa e Silva, Francisco Félix de Souza: mercador de escravos, Rio de Janeiro: EdUerj/Nova Fronteira, 2004, p. 82.
} 
conseguiu substituir o Daomé no comércio de escravos; o rei do Daomé fracassou em sua pretensão de ganhar o monopólio do comércio de escravos. D. João, por seu lado, parece ter saído ganhando: manteve o comércio de escravos, não só com o Daomé mas com outros portos da Costa da Mina, e não deixou em risco sua aliança com os ingleses. Por trás dos quatro missivistas aqui analisados que discutem os meandros da diplomacia estavam, silenciosos, os comerciantes de escravos situados de um lado e de outro do Atlântico. ${ }^{37}$

A correspondência entre Adandozan e d. João mostra a estratégia diplomática e comercial de d. João em 1811. A historiadora Ismênia de Lima Martins, estudiosa de d. João, destaca de modo bastante enfático a simpatia do príncipe pelo comércio de escravos. Martins mostra ainda que não apenas d. João mas seu governo foram insistentes em resistir a pressões inglesas. A historiadora volta ao clássico livro de Oliveira Lima, D. João VI no Brasil, e nele recupera um registro do cônsul francês Maler que declara sua impressão de que d. João defende veementemente o comércio atlântico e a escravidão. Martins mostra que "quando Dom João VI, regressou a Portugal (1821), a disputa não estava resolvida, o que era um sinal de vitória". ${ }^{38}$ Sua análise ajudou a compor o quadro aqui apresentado no qual o príncipe, seguindo as relações de amizade de seu pai, mantém, mesmo que à distância, uma ligação com os soberanos africanos para garantir o comércio de escravos na Baía do Benim. As ligações entre eles ainda precisam ser melhor estudadas. Infelizmente, parecem estar fora do foco de interesse da maioria dos historiadores do período joanino.

Se, nas grandes decisões dos rumos do Império português, deve-se considerar a capacidade de articulação dos ministros e os interesses

\footnotetext{
37 Importante destacar que, paralela a essa correspondência diplomática, corria uma regular correspondência comercial. Um caso bem posterior que mostra a longevidade dessas práticas está sendo estudado por Alexandre Vieira Ribeiro a partir da correspondência comercial entre o rei Kosoko, de Onim (Lagos) e seus agentes em diversos portos, especialmente Bahia/Brasil e Cuba, entre 1848-1850. Alexandre Vieira Ribeiro, "Conexões mercantis do rei de Onim em meados do século XIX", in Alexandre Vieira Ribeiro e Alexsander L. A. Gebara (orgs.), Estudos Africanos: múltiplas abordagens (Niterói: EdUFF/PPGHIS, 2013), pp. 430-51.

38 Ismênia de Lima Martins, "Dom João - Príncipe Regente e Rei - um soberano e muitas controvérsias", Navigator, v. 6, n. 11 (2011), pp. 32-3; Oliveira Lima, D. João VI no Brasil, Rio de Janeiro: Topbooks, 1996, p. 271.
} 
econômicos envolvidos, nesse caso a atitude pessoal de d. João e a longevidade das relações diplomáticas e comerciais entre Portugal e os reinos africanos parecem ter pesado no comportamento do príncipe. Tanto d. João quanto Adandozan se comportam como monarcas herdeiros de antigos laços comerciais que correm o risco de se esgarçar. A troca de cartas e presentes segue uma diplomacia que já começa a se mostrar anacrônica diante dos novos tempos e das novas questões que o século XIX apresenta, mas que ainda se prolongam nas práticas comerciais, na diplomacia e no pensamento de muitos dos homens influentes na política daqueles tempos. ${ }^{39}$

\section{A diplomacia das cartas}

Ao ler as cartas dos soberanos africanos, é importante ter em mente que elas são sempre escritas por terceiros, o que muitas vezes interfere no seu conteúdo e forma. A carta de Adandozan tem uma narrativa muito particular, indicando ter sido efetivamente ditada por ele. $\mathrm{O}$ fato de se dirigir a d. João como "meu irmão", e os comentários sobre a humilhação da família real portuguesa ("prisioneiros do Francês") são exemplos de uma fala própria, e não de terceiros. Somente ele, por meio de um subalterno a seu mando, teria tido o destemor de escrever tais coisas. Não existe indicação de quem teria redigido a carta, mas seu autor é, sem dúvida, o rei Adandozan. A partir da descrição detalhada — não necessariamente verdadeira - de suas vitórias nas guerras contra os reinos vizinhos de Ardra e Mahi, Adandozan dá uma demonstração de força a um d. João enfraquecido, corrido de sua terra, "retirado de baixo de uma armada inglesa e portuguesa, à cidade da Bahia". ${ }^{40}$ Por fim, o caráter diplomático da correspondência fica claro quando Adandozan, usando da retórica de aliança e da amizade, oferece ao rei de Portugal "um socorro com o meu braço". Assim é que, com uma quase explícita

\footnotetext{
39 Ver Jaime Rodrigues, "O tráfico de escravos e a experiência diplomática afro-luso-brasileira: transformações ante a presença da corte portuguesa no Rio de Janeiro", Anos 90, v. 15, n. 27 (2008), pp. 107-23.

40 Em seu texto, Thornton aponta para as intenções de Adandozan no sentido de "revelar a seu irmão lusitano que ele poderia estar em condições de ajudá-lo contra seus inimigos". Ver John K. Thornton, "Dahomey in the World".
} 
ironia, inicia sua carta expressando seu pesar pela situação de Portugal. Já na primeira página da carta escreve:

[...] começaram a chegar as notícias de que Vossa Real Alteza e toda a família real tinham sido prisioneiros dos franceses e que tinham tomado Lisboa, e juntamente o rei de Espanha[.] Passado o decurso do tempo, veio outro navio que trouxe novas notícias que Vossa Real Alteza, e a nossa soberana mãe, a rainha de Portugal, se tinham retirado, debaixo de uma armada inglesa e portuguesa, à cidade da Bahia. Passado o decurso de tempo, veio outro navio trouxe por notícia que se tinha passado para o Rio de Janeiro. Aonde também soubemos que morreu o duque de Cadavâl, do que eu senti muito, e disso the dou os pêsames[.] Pois o tempo tudo está virado, em o [palavra corroída] tempo do nosso governo tanto lá como cá, [palavra corroída] o meu sentimento tem sido de eu não ficar mais vizinho de Vossa Alteza, e nem poder andar em terra firme para lhe dar um socorro com o meu bra-ço, pois a minha vontade é grande[.] Pois eu também cá na minha terra tenho pelejado muitas guerras pelos sertões adentro, tanto da nação maquinos, como de nagôs, e desses todos tenho tido vitória[.] ${ }^{41}$

Amparando-se na tradição das três embaixadas anteriores (1750, 1795 e 1805), Adandozan pede explicações sobre a mudança de atitude do "irmão", perguntando sobre o motivo de não serem seus embaixadores autorizados a ir ao Rio de Janeiro. Provavelmente se referindo à ordem de 1805, diz: "eu já ouvi cá notícia de que na Bahia há ordem dos meus embaixadores, se lá forem, não passarem da Bahia e virem para minha terra retirados". Mais adiante, continua: "quando eu ouvi essa notícia não pude acreditar, porque não podia ser, porque um rei de Portugal nunca costumou virar embaixadores que ia na sua real presença". ${ }^{42}$

$\mathrm{O}$ fato de mencionar o assunto em sua carta mostra que Adandozan sabia da dificuldade em ter acesso direto a d. João e mesmo assim mandou a embaixada, forçando uma situação de antemão difícil. O embaixador do Daomé chega à Bahia em janeiro de 1811, portanto cerca de três meses depois da data de assinatura da carta. O embaixador do rei de

\footnotetext{
41 Parés, "Cartas do Daomé", carta 13, p. 378

42 Parés, "Cartas do Daomé", carta 13, p. 384.
} 
Ardra, que chegara em dezembro, deve ter partido em outubro/novembro. Dessa estimativa pode-se deduzir a possibilidade de que a embaixada de Adandozan tivesse sido motivada pela notícia de que o rei de Ardra estava mandando emissários ao Brasil para aumentar seu comércio, em detrimento do comércio com o Daomé. Por outro lado, isso indica também que as embaixadas devem ter sido anunciadas, como de praxe, antes disso, ou seja, pouco tempo depois da assinatura do tratado entre Portugal e Inglaterra. Essa cronologia mostra ainda a regularidade dos contatos entre Brasil e os portos africanos e a rapidez com que as informações circulavam e influenciavam estratégias de ação dos dois lados do Atlântico.

\section{A diplomacia dos presentes}

Os presentes são resultado de demandas bem específicas detalhadamente listadas nas cartas. Tudo indica que parte desses pedidos eram atendidos, outros não. Em uma carta de 20 de março de 1795, Agonglo faz vários pedidos a d. Maria, então rainha de Portugal. Essa carta foi transcrita por Parés (carta 3) mas dela não consta a lista de pedidos porque, como esclareceu d. João em sua resposta (Anexo, carta 1), os pedidos não constavam do teor da carta, e sim de um adendo a esta, "um papel sem assinatura", que deve ter-se pedido. Mas sobre o tal adendo diz d. João:

Fora da Vossa Carta encontrei um papel sem assinatura em que Me pedíeis um bergantim pronto de tudo para a guarda desse Porto; como também um homem que soubesse bem ler, e escrever para ficar convosco, e finalmente pedis também, que vos enviasse um navio, cuja carga fosse de sedas boas de ouro, e prata em obra, e tudo os mais que pertence a um Rei, e finalmente quarenta peças de Bronze, e Ferro bastantemente reforçadas para guarnecer a Vossa Terra; a tudo isto procurarei satisfazer quando me seja possível logo que as circunstâncias me permitirem, porque na presente ocasião me é impossível fazê-lo, não só por falta de tempo, mas por outros diferentes motivos, de que é supérfluo informar-vos, desejando em tudo com prazer-vos, como cumpre a Minha Fiel Amizade. ${ }^{43}$

Não eram poucos os pedidos de Agonglo, e a eles d. João parece nun-

43 Para o rei Agonglo, ver Parés, "Cartas do Daomé", carta 3, pp. 335-41; para d. João, ver Anexo, carta 1. 
ca ter atendido, embora sempre renovando seus votos de "Fiel Amizade".

Na carta de 1810, Adandozan informa a d. João que, ao se tornar rei, encontrara em sua "casa" (o palácio de Abomé) oito guarda-sóis que teriam sido mandados por um rei de Portugal a seu bisavô. Seguindo a genealogia dos reis do Daomé, os guarda-sóis devem ter sido os tais presentes enviados por d. José ao rei Tegbessu (1732-1774) por ocasião da embaixada daomeana de 1750. Em demonstração da pompa desse antigo presente, Adandozan descreve, em sua carta de 1810, cada um deles: um era de veludo carmesim forrado de seda com franja de ouro em volta; outros dois de veludo verde e azul, também ornados, com maçanetas de ouro, rendas, espelhos, um deles ornado com leões, outros com espadas desembainhadas e espingardas. ${ }^{44}$

A riqueza dos presentes atesta o grau de amizade que unia os dois reinos há pelo menos três gerações (Tegbessu, Agonglo e Adandozan) de um lado, e duas de outro (d. José, depois d. Maria e d. João). Ao mesmo tempo em que fala dos presentes recebidos por seus antepassados, Adandozan apresenta sua "lista" de novos pedidos que, entenda-se, deveriam ser de equivalente valor. O primeiro é construção de uma capela para a qual pede dois pedreiros, tábuas, tinta, imagens de santos e mais adornos. Pede também dois sacerdotes e "relíquias para a defensa do corpo, para quando for às guerras me defender do inimigo". O segundo, equipamentos de guerra: "bombas ardentes de elevação" (supostamente balas de canhão), soldados capazes de manejar os canhões, 24 espingardas colubrinas de boa qualidade. Pede ainda bombas d'água, pipas de vinho, aguardente e vários animais. Tudo, segundo ele, para "causar admiração" a seu próprio povo: "meu rei não sabe ler nem escrever", mas, mesmo assim, "como tem tanta coisa de branco bonita na sua mão". ${ }^{45}$

Dentre os presentes enviados por Adandozan, os mais valiosos eram seis escravos, todos prisioneiros de guerra, "para eles mesmos pessoalmente noticiarem a Vossa Alteza sobre as guerras...". ${ }^{46}$ Não fica claro em que guerra os escravos enviados tinham sido feitos prisioneiros.

\footnotetext{
44 Parés, "Cartas do Daomé”, carta 13, pp. 389-90. A descrição lembra muito os guarda-sóis ainda hoje usados no Benim.

45 Parés, "Cartas do Daomé", carta 13, pp. 386-7.

46 Parés, "Cartas do Daomé”, carta 13, p. 391.
} 
Adandozan fala rapidamente de uma guerra contra os maís e descreve em detalhes seu ataque a Agonsa. Diz ter "quebrado" a terra de Agonsa porque os moradores de Agonsa ensinaram ao exército de Ardra o caminho para Abomé Calavi e que por isso a localidade, sob sua proteção, tinha sido destruída pelo exército de Ardra. Essa batalha contra Agonsa, segundo ele, lhe rendeu um título que ele descreve como "a porca pariu seus filhos, para num dia morrer a mãe com seus filhos". A explicação para esse título, segundo ele, é que "Agonsa é o filho da porca, e o Porto Novo é que pariu os filhos". Assim, na dita batalha ele derrota a porca (Porto Novo-Ardra) e o filho (Agonsa). Provavelmente, os escravos enviados a d. João eram prisioneiros feitos em Agonsa. ${ }^{47}$

Embora as palavras de guerra pontuem a carta, não se trata de uma correspondência de guerra e sim de amizade. Os presentes representam amizade e reciprocidade que se instala numa relação de suposto equilíbrio entre dois monarcas poderosos. E é a partir dessa reciprocidade que o comércio tem seu lugar. ${ }^{48}$ Com essa narrativa, Adandozan pretende mostrar a d. João que seu concorrente (o embaixador do rei de Ardra, na ocasião a caminho da Bahia) era um derrotado, não merecedor do privilégio do comércio com Portugal.

Por ora, os únicos presentes identificados nessa troca de correspondência são os que pertencem ao acervo do Museu Nacional, mas possivelmente, tanto no Brasil quanto em Portugal, devem existir outros. Segue a lista completa dos presentes que Adandozan chama de "galanterias", conforme listados e descritos na carta: dois alforjes, duas bolsas, dois pares de alpercatas, dois abanos, um coxim, quatro bastões, duas forquilhas, duas esteiras, sete panos, um calção, duas patronas, uma cadeira, quatro caixas de cachimbo, dois anéis de prata, um anel de ouro, dois fuzis, um chapéu de sol, uma bandeira. ${ }^{49}$

\footnotetext{
47 Mais adiante, no mesmo parágrafo, Adandozan diz: tomei eu mesmo o titulo o Imigôu a Funquijâ". Ao que indicam as expressões "me deram" e "tomei eu mesmo" são dois títulos diferentes, em razão da mesma batalha. Parés, "Cartas do Daomé", carta 13, p. 381.

48 Nunca é demais relembrar aqui o clássico "Essai sur le don" de Marcel Mauss publicado em 1923-24 e a farta literatura que sucedeu esse texto. Ver Marcel Mauss, "Ensaio sobre a dádiva. Forma e razão da troca nas sociedades arcaicas", in Marcel Mauss, Sociologia e Antropologia, v. 2, São Paulo: EPU/EdUSP, 1974, p. 35-184.

49 Parés, "Cartas do Daomé", carta 13, pp. 390-2. 
São todos objetos usados pelo próprio rei do Daomé e, portanto, compatíveis com o rei "irmão", inclusive o trono e as sandálias, cujo uso no reino do Daomé é privilégio régio.$^{50} \mathrm{O}$ envio de seis escravos mostra a riqueza dos presentes que curiosamente incluem dois fuzis. ${ }^{51}$ A mencionada "bandeira de guerra" descreve, pelos seus desenhos, a vitória do Daomé sobre Agonsa e Ardra e o sacrifício dos prisioneiros. A decapitação dos vencidos na guerra, seja no próprio campo de batalha, seja em cerimônias posteriores organizadas com essa finalidade, é uma prática usual no Daomé e em outros reinos da mesma região. ${ }^{52}$

A bandeira que traz aplicações em pano com as cabeças dos prisioneiros cortadas, pingando sangue é feita em pano cru, um tipo de linho, possivelmente da mesma qualidade do descrito por Adandozan como "linhos de minha terra", com aplicações em tecido. Segundo Verger, essas aplicações feitas em Abomé são exclusividade da família Yémadjé. ${ }^{53} \mathrm{~A}$ bandeira é uma dramática alegoria do poder bélico de Adandozan, ofertada a um rei expatriado e enfraquecido por sua derrota incruenta frente aos franceses:

Também remeto uma bandeira das guerras que é da gente que apanhei e das cabeças que cortei, por sinal para meu irmão ver, e trazer diante de si quando sair à rua aos seus passeios[.] São as cabeças dos cabeceiras, e também os que estão amarrados são cabeceiras, e os dois que estão na bacia são os dois cabos de guerra grandes, um chamado a Dangogy, e o outro chamado Gorumap[ô], e o pau de cachaporra foi com que se matou o dito a Dangogi; e mais um dos grandes que apanhei vivo chamado Thofuião que está aí amarrado[.] $]^{54}$

${ }^{50}$ Law, Ouidah, p. 121

${ }^{51}$ Uma parte dos presentes está listada no livro de registros do Setor de Etnologia e Etnografia (SEE) do Museu Nacional, dentre eles: as duas bolsas; um dos pares de alpercata; os dois abanos; as quatro bengalas (ou bastões); três dos sete panos; a cadeira (ou trono); as caixas de cachimbo; e a bandeira de guerra. Dentre as peças mais importantes estão, sem dúvida, a cadeira e a bandeira de guerra, peça única sem similar conhecido. Tanto o trono quanto a bandeira têm sido referidos em vários textos. Ver Pierre Verger, "Uma rainha africana”; Alberto da Costa e Silva, "Uma visão brasileira"; Araújo, "Dahomey, Portugal and Bahia".

52 Sobre a decapitação de prisioneiros de guerra, ver Robin Law, “"My Head Belongs to the King”: on the Political and Ritual Significance of Decapitation in Pre-Colonial Dahomey", The Journal of African History, v. 30, n. 3 (1989), pp. 401-6.

53 Ver menção aos linhos da terra na carta de Adandozan a Francisco da Cunha Menezes, governador da Bahia (1804) mencionada por Parés. Ver, também, Parés, "Cartas do Daomé”, pp. 352-3, nota 95, com as informações sobre o artesanato em pano, extraídas de Verger (Os libertos, p. 80).

${ }^{54}$ Parés, "Cartas do Daomé", carta 13, p. 392. 


\section{A diplomacia dos bastões e das bandeiras}

Outro aspecto que tem sido desprezado na diplomacia é o uso dos bastões e das bandeiras, para os quais as cartas chamam atenção. Bandeiras e bastões são mencionados várias vezes ao longo das cartas, com diversos usos, sendo necessária uma contextualização de sua presença na correspondência, para chegar-se a uma apurada identificação de cada objeto. Pela leitura da carta de Adandozan se conclui que existem bandeiras e bastões de vários tipos. Adandozan descreve as normas de negociação tanto para a guerra quanto para o comércio, e, nos dois casos, bastões e bandeiras têm papel de destaque. A bandeira oferecida a d. João é uma "bandeira de guerra", diferente, por exemplo, das usadas na identificação das embarcações e dos fortes. Diferente também das bandeiras portuguesas que Adandozan pede a d. João:

Pois uma das dádivas que meu irmão pode mandar para mim e os meus cabeceiras é uma bandeira com um leão no meio, e outra da sua casa de Bragança, para quando eu sair, andar diante de $\operatorname{mim}[.]^{55}$

Os bastões que fazem parte da lista dos presentes são "bastões de passeio", bengalas ("quatro bastões para trazer na mão quando for ao passeio da sua quinta" ${ }^{56}$ ), diferentes dos enviados pelo rei por meio de suas embaixadas e que representavam o poder real. ${ }^{57}$ Em suas memórias sobre o Daomé, datadas de 1806, António de Oliveira Mendes afirma que os embaixadores daomeanos eram chamados "larins" (o termo moderno usual é laris). Segundo ele, os laris "têm parte da cabeça rapada, ou uma poupa de cabelo, e ao embaixador se entrega o bastão, figurando ser o do rei, para [que] se tenha a embaixada por verdadeira". ${ }^{58}$ Na primeira

\footnotetext{
55 Parés, “Cartas do Daomé”, carta 13, p. 390.

56 Parés, "Cartas do Daomé", carta 13, p. 391.

57 Sobre os bastões, ver Alexandre Sènou Adandé, Les récades des rois du Dahomey, Dakar: IFAN, 1962. Também pequena nota em Parés diz ser o bastão representação simbólica do rei, carregado pelos laris (embaixadores) em nome de sua segurança e imunidade. Ver Parés, "Cartas do Daomé", carta 12, p. 360, nota 135.

58 O original da memória de Oliveira Mendes pertence ao IHGB (DL310,79 - registro número 812 do Inventário analítico. Wanderley "Inventário analítico". O texto transcrito pelo projeto do Inventário foi publicado com comentários de Alberto da Costa e Silva. Ver Alberto da Costa e Silva, "A memória histórica sobre os costumes particulares dos povos africanos, com relação privativa ao Reino da Guiné, e nele com respeito ao rei de Daomé, de Luis Antônio de Oliveira Mendes", Afro-Ásia, n. 28 (2002), p. 272.
} 


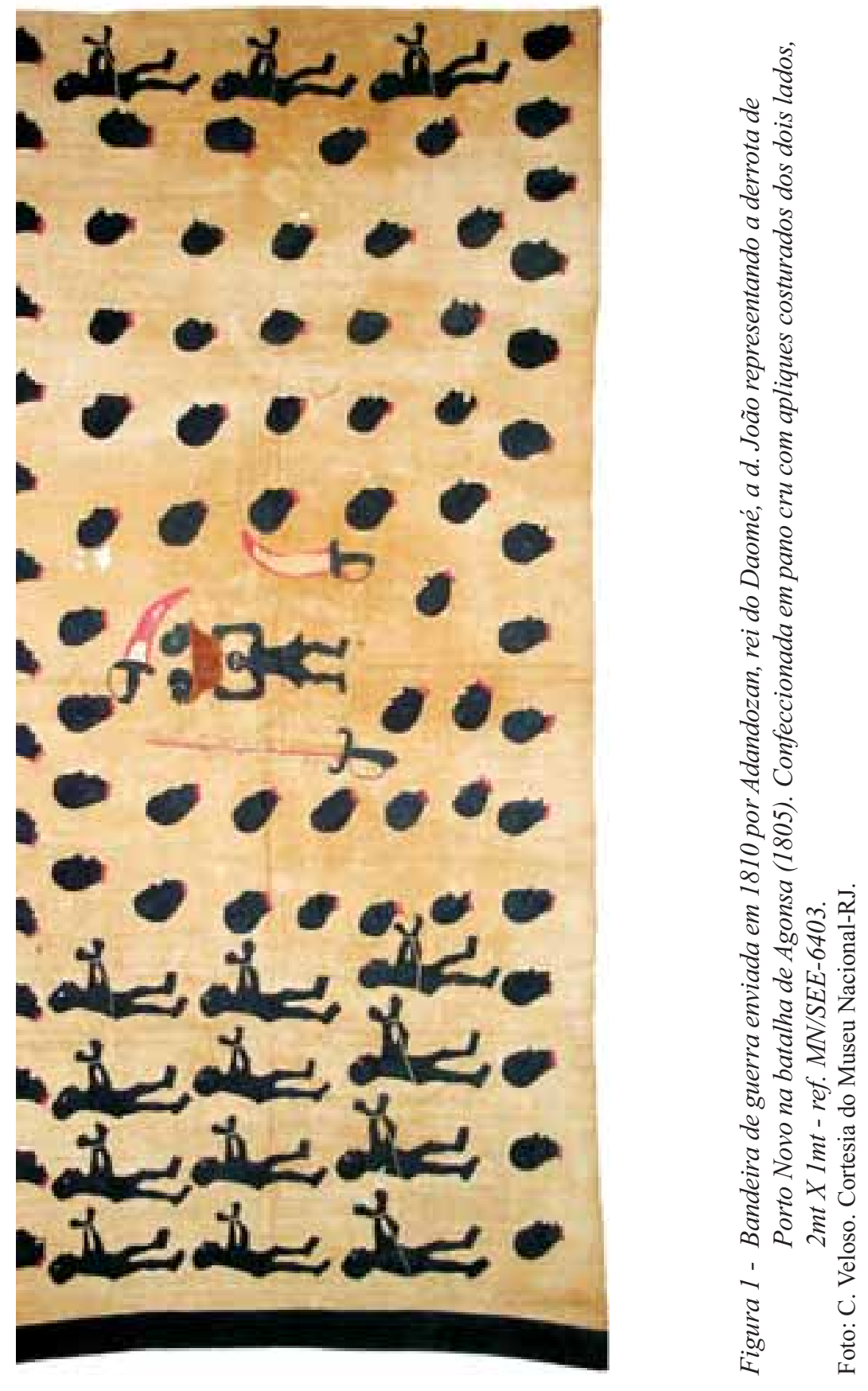

Afro-Ásia, 49 (2014), 229-271 253 
folha de sua carta de 1810, Adandozan se lamenta a d. João de seus problemas com o comércio de escravos e das atitudes do rei de Ardra/ Porto Novo e dos comerciantes portugueses e brasileiros estabelecidos na costa (Ajudá, Porto Novo, Popô, Apê e outros portos).

Em outra carta, de 1805, Adandozan alega ter enviado seu bastão quatro vezes para encontrar um acordo para as desavenças que terminaram na batalha de Agonsa, representada na bandeira:

Mandando eu o meu bastão com um enviado, acompanhado com quarenta homens, ao rei de Apê a contratar um negócio, aonde o rei de Arda soube que eu tinha mandado essa embaixada, mandou um cabo de guerra seu aprisionar a minha gente; donde os levaram. Eu sabendo disso, mande-lhe o meu bastão dizendo-lhe que aonde se viu aprisionar enviados, e que me os remetesse, e a reposta que me mandou foi que os havia de matar, ou vendê-los..$^{59}$

Diante da irreversibilidade do conflito contra Ardra, Adandozan explica a d. João ter recomendado ao governador do forte português de Ajudá que ficasse longe de Porto Novo porque ele iria invadir aquelas praias para fazer guerra. Em seguida, descreve em detalhes a participação de Apê e do Popô, reinos vizinhos, no conflito. Complementa explicando que mandou seu bastão ao rei do Popô, seu aliado, dizendo que juntasse os "capitães" e os mandasse para Porto Novo, onde havia muitos cativos à venda.$^{60} \mathrm{Ou}$ seja, o rei de Porto Novo queria que os capitães dos navios europeus e do Brasil comprassem escravos no Popô e não em Ajudá, esvaziando o comércio do Daomé. Entre os compradores de escravos que vão para o Popô está o capitão Felix da Costa Lisboa e um capitão inglês que, junto com o rei de Ardra, teriam ajudado a atacar Abomé Calavi.

Adandozan dá detalhes do conflito e questiona a atitude dos portugueses contra ele, dizendo que "o capitão Felix da Costa Lisboa e um navio inglês" ofereceram ajuda ao rei de Ardra com "pólvora e bala" para esse "vir quebrar uma terra minha chamada Abome de Calavê" onde

59 Parés, "Cartas do Daomé", carta 12, p. 360. Em 1804, o rei de Ardra era Hypo que assina a carta escrita a d. João, transcrita por Verger. Verger, Fluxo e refluxo, p. 275.

${ }_{60}$ Era de praxe os capitães das embarcações serem os responsáveis pelo comércio dos escravos embarcados. Apenas embarcações de grande porte levavam um representante comercial para montar feitoria e se encarregar do comércio. 
"fizeram destruição matando, aprisionando tudo quanto acharam". Diz então que, quando soube do ataque, mandou seu bastão ao capitão Felix perguntando "se meu irmão o rei de Portugal tinha guerra comigo, e se mandava ele dar suprimento a outro qualquer rei para vir fazer guerra comigo." ${ }^{61}$ Esse é, portanto, o verdadeiro motivo do conflito que levou ao ataque de Adandozan a Agonsa: a disputa entre Ardra e Daomé pelo comércio de escravos, motivo que explicava o envolvimento de portugueses e ingleses no conflito. Segundo Parés, o ataque a Abomé Calavi aconteceu entre o fim de 1802 e o início de 1803, e o ataque a Agonsa em 1805 ou posteriormente. ${ }^{62}$ Em consulta a Robin Law, esse historiador me informou que, segundo suas anotações, a batalha contra Agonsa aconteceu em $1805 .{ }^{63}$

A carta de Adandozan fala repetidas vezes dos bastões que manda para negociar tanto guerras quanto comércio, mas nela não há qualquer menção a ter mandado um bastão ao Brasil com seu embaixador, em 1810. Entretanto, da mesma forma que o embaixador de 1750 traz um bastão enviado por Tegbessu, certamente o embaixador de Adandozan, em 1811, também traz um. ${ }^{64}$ Ao que tudo indica, os bastões de diplomacia são um costume de toda a costa. Em 1824, o rei de Onim manda uma embaixada ao Brasil. Dessa vez, apesar dos transtornos da difícil viagem, o embaixador chega ao Rio de Janeiro, onde pede para ser recebido pelo imperador d. Pedro I, se apresentando como embaixador do

${ }^{61}$ Parés, "Cartas do Daomé”, carta 12, p. 361.

62 Parés, "Cartas do Daomé", p. 361, nota 141, p. 381, nota 254 e "Introdução", p. 315 , nota 56.

63 Segue a mensagem recebida de Robin Law: "I managed to find my old $\mathrm{PhD}$ notes (from $40+$ years ago!) and found the following. The National Archives (TNA), T70/1163, Day Book, William's Fort, Whydah, 21 March 1805, refers to messagers bringing to Ouidah the heads of "Adahoonsey, Captain General \& several other Porto Novo caboceers who were slain in war by the Dahomans". NB also that Edouard Dunglas,"Origine du royaume de Porto-Novo", Études dahomeennes, nouvelle série, 9-10 (1966), 29-42, records a war fought by De-Gbegnon, King of Porto-Novo, against Adandozan (see pp. 33-34). It is said that the Dahomians first invaded PN territory and penetrated to Lowo on the north bank of the lagoon, $5 \mathrm{~km}$ from Porto-Novo, but were chased away. But "a few months after" the Dahomians came back, defeated the PN forces, and "pillaged and destroyed the villages of the region of the Atlantic: Djeffa, Ekpe, Agonsabo [= Agonsa?], Goho, Ketonou ... Krake, Podji, Gbehoome". This looks like your 1804 war". Cópia de e-mail datado de Monday, January 02, 2012 7:19 PM.

64 A documentação faz constantes referências a "bastões", mas, ao que tudo indica, a palavra é usada para designar objetos bem diferentes, sendo por isso difícil saber a que se refere em cada situação. Em nenhum momento fica claro que seriam os conhecidos "récades" dos reis do Daomé. Ver Adandé, Les récades. 
imperador do Benim e dos reis africanos, entre eles o rei Ajan, do reino de Onim (mais conhecido como Lagos, nome português de seu porto). Por indicação de Alberto da Costa e Silva, Verger menciona a embaixada de Onim a partir de um texto anônimo publicado na Revista do IHGB (1891), destacando o fato de que, por intermédio do embaixador Manoel Alves de Lima, o rei de Onim teria sido o primeiro monarca a reconhecer a independência do Brasil. ${ }^{65}$

Manoel Alves de Lima, que Verger suspeita ser um negociante de escravos ${ }^{66}$ vem de posse de um bastão e de uma carta que quer "depositar na Augusta Mão de V. M. I.", conforme "encarregado nesta Missão pelos citados Soberanos". O dito embaixador "e seus fâmulos" (como são chamados na correspondência da burocracia imperial) permanecem na cidade por vários meses aguardando d. Pedro I, o que também faz parte dessa diplomacia. Em 17 de agosto, recebe a recomendação de ir "a casa da sua residência (possivelmente o Palácio da Quinta da Boa Vista) receber a sua 'bengala' e retirar-se quando quiser". ${ }^{67}$ Por esse aviso fica claro que os tais "bastões" (ou "bengalas") são representações da realeza nas missões diplomáticas e comerciais e por isso se fazem presentes nas negociações do ultramar. ${ }^{68}$ Encerradas as negociações, os bastões são devolvidos e retornam junto com os emissários seus portadores. Certamente por isso, não se encontram bastões entre os presentes, e pelo mesmo motivo os embaixadores são tão zelosos deles. ${ }^{69}$

\footnotetext{
65 "Reconhecimento da independência do império do Brazil pelos reis d’África", texto sem autor, publicado na Revista do Instituto Histórico e Geográfico Brasileiro, v. 54 (1891), pp. 161-2. Nessa memória, consta que o documento estava no "Archivo Publico do Brazil", atual Arquivo Nacional. Os documentos encontrados em 1891 no Arquivo Público podem ser os mesmos hoje depositados no Itamarati ou outra via ou cópia da mesma correspondência.

66 Verger, Fluxo e refluxo, pp. 283-4.

${ }_{67}$ Documentação atualmente sob a guarda do Arquivo Histórico do Itamarati: Pasta 06 - Missões Especiais estrangeiras diversas - África, Argentina e Bolívia. 1824-1920 - 273/1/13. Alberto da Costa e Silva analisou e a embaixada publicou duas cartas, mas não a tramitação burocrática da embaixada no Rio de Janeiro. Ver Alberto da Costa e Silva, "Cartas de um embaixador de Onim", Cadernos do $C H D D$, v. 4, n. 6 (2005), pp. 195-205 (periódico do Ministério das Relações Exteriores publicado pela Fundação Alexandre de Gusmão e pelo Centro de História e Documentação Diplomática).

68 Em sua carta a d. João, Adandozan lista o envio de quatro "bastões". No Museu Nacional, junto com os demais presentes, encontrei quatro bengalas de madeira clara, de desenho europeu e não os conhecidos récades.

${ }^{69}$ Curiosamente, o Museu Nacional tem uma coleção de "bastões" de Angola que parecem cumprir função análoga. Fica para estudos futuros pensar em que medida foram difundidos em toda a extensão do Atlântico onde os portugueses estabeleceram relações comerciais e diplomáticas com autoridades
} 


\section{A diplomacia do silêncio régio}

É indispensável destacar a participação do conde das Galveas, conselheiro de Negócios Estrangeiros, nesse episódio. Experiente em assuntos diplomáticos, o conde entra em cena para dar a palavra final sobre os destinos das duas embaixadas que tanto incômodo trazem ao governador da Bahia. Em sua primeira carta ao conde dos Arcos, escrita no Palácio do Rio de Janeiro, em 2 de agosto de 1811, diz que fizera chegar ao príncipe regente o oficio do governador de 7 de maio, dando ciência do problema das embaixadas em Salvador e a ele encaminhando o conjunto das cartas recebidas (não menciona os presentes). Logo de início, destaca o conflito quanto às pretensões dos dois reis africanos. Enquanto o rei do Daomé propõe monopólio do comércio de escravos, o rei de Ardra admite o livre comércio ("que o segundo facilita e oferece o seu mediante toda a qualidade de cooperação da sua parte, para tornar mais vantajoso e seguro"). Mostra perceber acusações que se fazem mutuamente os dois "régulos" e, em seguida, passa às questões colocadas pelo conde dos Arcos. Responde, então, à pergunta sobre "a verdadeira inteligência do Art. X do Tratado de Aliança de 19 de fevereiro de 1810" e sobre "seguir uma gradual abolição do Comércio de Escravatura". Diz que, diante das perguntas, decidira fazer consulta ao Ministro e Secretário de Estado dos Negócios Estrangeiros e da Guerra, conde de Linhares, que fora o negociador do tratado, e responde ao governador nos seguintes termos:

Que o nosso tráfico de Escravatura deveria continuar se não só naqueles portos, pertencentes ao Domínio de Sua Alteza Real e naqueles a que se julgasse com direito a Sua Coroa, mas ainda em todos os mais em que os seus vassalos se achassem em posse de fazer aquele comércio. E transmitindo a Vossa Excelência a cópia da resposta que me deu o mencionado Secretário de Estado, em que confirma esta mesma inteligência, devo acrescentar a Vossa Excelência, por ordem de Sua Alteza Real, a declaração de que, longe de ser da Sua Real Intenção restringir de qualquer modo semelhante comércio, o Mesmo Senhor se propõe a promovê-lo e facilitá-lo, quanto se possa, bem convencido da necessidade

políticas locais. A coleção de bastões de Angola do Museu Nacional data do século XIX e início do XX. Há referências frequentes a seu uso pelos sobas. Suspeito que tais bastões tenham sido capturados ao longo de conflitos coloniais em Angola. 
que há, de lançar mão deste único recurso, que temos, de aumentar a população deste vasto continente, onde há tão sensível falta de braços, que Vossa Excelência conhece, não só para a agricultura mas para toda a qualidade de trabalhos. ${ }^{70}$

Seu segundo oficio é datado de 21 de março de 1812 e responde a outro do conde dos Arcos, datado de 24 de fevereiro de 1812, quando o governador ainda está às voltas com os embaixadores que permaneciam na cidade. Galveas escreveu ao conde dos Arcos uma de suas últimas cartas, antes que a doença passasse a impedi-lo de continuar. Já em maio de 1812, é o conde de Aguiar o encarregado das negociações do tratado junto ao governador da Bahia. ${ }^{71}$ Nessa suposta última carta, Galveas volta a discutir a questão da permanência dos embaixadores africanos na Bahia. ${ }^{72}$

Galveas é bem claro na decisão de mandá-los partir: “conviria fazer retirar para sua Pátria, com a brevidade possível". ${ }^{73}$ Mas também determina com precisão as formalidades a serem cumpridas, segundo determinações de d. João. O interessante é que, em 1812, d. João já não se dirige aos reis como fizera em 1811, quando escreve ao rei de Ardra explicando sua proibição. Simplesmente, ordena ao secretário de Negócios Estrangeiros, o conde das Galveas, que transmita suas ordens ao conde dos Arcos, para que ele as faça chegar aos embaixadores:

[...] e havendo já Sua Alteza Real mandado dar de presente ao chefe daquela embaixada uma bandeja de um aparelho completo de chá, ordena que Vossa Excelência quando julgue a propósito a bem do tráfico e relações que temos com os territórios donde eles vieram, e sendo essa prática que aí se tem seguido em semelhantes ocorrências, mimosear os mesmos Embaixadores o faça, regulando-se em tal caso na devida pro-

\footnotetext{
70 BN-RJ. Ofício do conde das Galveas ao conde dos Arcos, escrito no Palácio do Rio de Janeiro, 02.08.1811 (Anexo, carta 4).

71 Verger transcreve parcialmente uma carta de 21 de maio de 1812 , assinada pelo do conde de Aguiar, indicando ter sido ele o encarregado de continuar as negociações com o conde dos Arcos no que diz respeito ao comércio de escravos e aos tratados de 1810 frente aos comerciantes da Bahia (segundo a referência de Verger: AEB, 112). Verger, Fluxo e refluxo, p. 333.

72 BN-RJ. Ofício do conde das Galveas ao conde dos Arcos, escrito no Palácio do Rio de Janeiro, 21.03.1812. Anexo, carta 5.

73 Note-se que a carta é datada de 21 de março de 1812 . Estão já há mais de um ano na cidade e ainda aí permaneceram por vários meses.
} 
porção do Presente que Sua Alteza Real lhes mandou dar, e conciliando a conveniente e necessária decência que se deve guardar a semelhante respeito com as atuais [urgências] de Estado. ${ }^{74}$

A carta de 21 de março, bem mais curta que a anterior, tem um tom de encerramento de negociações. As condições de comércio estão já estabelecidas na carta anterior, que recusara o monopólio e deixara os acordos comerciais por conta do bom senso do governador e dos interesses dos comerciantes. A diplomacia da amizade recomenda a troca de presentes e a preservação das hierarquias, como de costume. Como em todas as cartas, o entrelaçamento entre comércio e diplomacia se repete por meio do ritual dos presentes, prova da renovação dos laços de amizade. Também como em ocasiões anteriores, nem todos os pedidos são atendidos, mas as relações tampouco são rompidas, deixando transparecer um d. João que, pela ação do conde das Galveas, se mantém distante dos acontecimentos, mas garante, mesmo assim, os "braços" de que necessita. De um lado, Galveas esclarece as dúvidas do conde dos Arcos, usando para isso o compromisso do conde de Linhares, de outro, poupa o monarca de despesas consideradas inúteis e ainda de trazer à baila sua simpatia pelo comércio de escravos.

Assim sendo, o conjunto da correspondência analisada, de um lado, insere os reinos africanos no debate da extinção do tráfico entre Portugal e Inglaterra e, de outro, mostra uma diplomacia que cruza diferentes conjunturas internacionais do comércio de escravos, da qual d. João é um exemplo. Mostra também como essa diplomacia é flexível ao tempo e às mudanças. Em 1812, para fazer valer suas vontades, d. João conta com a determinação do conde das Galveas frente às investidas do conde dos Arcos. A dimensão da participação de Galveas nas negociações que se sucedem ao Tratado de Aliança e Amizade ainda está por ser estudada. Talvez por ter falecido em 1814, d. Francisco de Almeida de Melo e Castro, $5^{\circ}$ conde das Galveas, tenha sido deixado de lado pela historiografia do Brasil em geral e da escravidão em particular. De todo modo, nesse episódio, foi o portador da palavra de d. João e, provavelmente, colaborou de modo ativo na definição das atitudes régias

74 Anexo, carta 5. 
nesses primeiros anos dos tratados de 1810, já que, em várias ocasiões, esteve envolvido nos debates sobre os rumos do comércio de escravos na cena internacional.

Finalmente, em 1812, a embaixada do Daomé embarca no bergantim Pistola com destino ao porto de Ajudá, e a embaixada de Ardra, no bergantim Constante com destino a Porto Novo. ${ }^{75} \mathrm{O}$ Pistola era de propriedade de Raimundo José Pereira do Vale e de Domingos Pacheco Pereira, que era também proprietário do Constance. Sob a responsabilidade do capitão Antônio Narciso, o Pistola deixa a Bahia rumo à Costa da Mina em 15 de outubro de 1812. Provavelmente nessa viagem, teria levado como passageiros os membros da embaixada do rei do Daomé, com destino ao porto de Ajudá, de onde devem ter retornado a Abomé para prestar contas da viagem a Adandozan. O Pistola volta à Bahia em 15 de agosto de 1813 , trazendo 366 escravos. $^{76}$

A correspondência de d. João com os monarcas do Daomé aqui analisada traz à luz um lado pouco divulgado da atuação de d. João no Brasil, mostrando seu longo envolvimento com uma diplomacia que suporta o comércio de escravos entre Portugal e Brasil e os reinos da costa ocidental africana, em especial o reino do Daomé. Essas trocas de cartas e presentes podem ser tratadas como uma diplomacia, na medida em que mostram uma regularidade ao longo do tempo, assim como o estabelecimento de práticas bastante próprias que se mantêm mesmo em condições difíceis, como os anos que sucedem ao Tratado de Aliança e Amizade. O modo como d. João trata a relação de Portugal e do Brasil com os reinos africanos deve ser entendido dentro desse contexto particular. Recupero aqui a análise de Ângela de Castro Gomes, em seu trabalho sobre as correspondências interpessoais como um gênero literário. A autora trata do que chama "cartas de si" para mostrar que uma identidade própria aos correspondentes vai se construindo no próprio tempo e na enunciação da escrita. ${ }^{77} \mathrm{O}$ d. João da correspondência com Adandozan

\footnotetext{
75 Verger, Fluxo e refluxo, p. 283.

76 O banco de dados The Trans Atlantic Slave Trade Database registra três viagens da Pistola: 7334, 7356 e 47178. O terceiro registro parece conter erros. < http://www.slavevoyages.org/tast/ database/search.faces>, acessado em 21.07.2013.

77 Ângela de Castro Gomes, "Escrita de si, escrita da História: a título de prólogo", in Ângela de Castro Gomes (org.), Escrita de si escrita da história (Rio de Janeiro: FGV Editora, 2004), pp. 7-24.
} 
está enredado nessas duas realezas, e é nesse lugar que se estabelecem os parâmetros que se estendem ao longo do tempo e se convertem em sólidos laços de amizade (no sentido da diplomacia da época) e comércio. Por ser o monarca que participou por mais tempo dessa correspondência, certamente teve um papel decisivo no estabelecimento dos parâmetros não só da correspondência e da diplomacia, mas do próprio comércio que a partir delas se estabelece.

Em sua carta de 1796, d. João se mostra um monarca apegado à retórica e às diretrizes estabelecidas por seus antepassados e um ativo representante dessa "amizade": "Nobre e Honrado rei de Daomé"; "vossa estimada carta"; "aquele apreço, e que sempre fizeram os senhores reis meus predecessores"; "estreitar cada vez mais os vínculos de amizade". Em 1811, muda seu tom; ao saber que o momento assim o exige, silencia. Mas, no seu silêncio, renova esses laços mediante o bom tratamento que a burocracia do Rio de Janeiro e da Bahia dá aos embaixadores: são recebidos com pompa, batizados e recebem presentes do rei e do governador. Certamente, levam outros presentes de outras autoridades e comerciantes interessados em manter relações amistosas com seus parceiros comerciais.

Apesar da mudança no contexto internacional e dos novos ares que vêm da Inglaterra, d. João protege os comerciantes de escravos e se renova como um rei escravista que troca "galanterias" com reis africanos traficantes. 


\section{ANEXO \\ TRANSCRIÇÃO DAS CARTAS DE D. JOÃO, DO REI DE ARDRA, DO CONDE DOS ARCOS E DO CONDE DAS GALVEAS*}

\section{Carta 1: IHGB: DL 137,62}

De: príncipe d. João (em nome de sua mãe rainha D. Maria I de Portugal)

Para: rei Agonglo do Daomé

Local e data: Palácio de Queluz, 06.01.1796.

Transcrição e atualização ortográfica por Flávia Maria de Carvalho

\section{(fl. 1) Cópia}

Nobre e Honrado Rei de Dagomé.

Dona Maria por graça de Deus Rainha de Portugal e dos Algarves, daquém e dalém Mar em África, Senhora de Guiné, e da Conquista, Navegação, e Comércio da Etiópia, Arábia, Pérsia e da Índia. [Vossa Excelência] Os Embaixadores, que enviastes à minha Corte de Lisboa Me entregaram a Vossa estimada Carta de vinte de março de mil setecentos e noventa e cinco, que Presei com aquele apreço, e que sempre Faço da Vossa Nobre Pessoa, e que sempre fizeram os Senhores Reis meus Predecessores, Desejando estreitar cada vez mais os vínculos de Amizade, e boa união, que felizmente tem subsistido entre os Nossos Vassalos e Estados para aumento e prosperidade de um comércio recíproco: e portanto não podia deixar de Me ser sinceramente sensível, que o Diretor da Fortaleza de Ajudá, Francisco Antônio da Fonseca e Aragão se esquecesse tanto das obrigações do seu Porto, que só se chegasse a lembrar dos seus interesses particulares; dando-vos motivos de desgosto, o que sinto sobre tudo.

E tendo-Me chegado notícias por outras vias do seu mau comportamento, e da infração, que tinha feito às Minhas Leis e Ordens, já Eu tinha prevenido os vossos desejos destituíndo-o do seu Emprego, e nomeando-lhe um sucessor para o vir render muito antes que chegassem à Minha Corte os Vossos Embaixadores; esperando que o que novamente se acha nomeado, (fl. 1v) não só se conformará exatamente com as Minhas Reais Resoluções, mas Vos dará provas convincentes da sua condescendência em tudo quanto possa ser da Vossa Satisfação e agrado, na forma, que expressamente lhe recomendo.

\footnotetext{
* Para facilitar a leitura, ortografia, gramática e pontuação foram atualizadas. Foram mantidas as letras maiúsculas características da época.
} 
Fico na inteligência do mau estado em que se acha essa Fortaleza, tanto a respeito dos dois Baluartes demolidos, como da sua Artilharia descavalgada, sem carretas, e portanto Passo as Ordens mais precisas ao Governador e Capitão General da Bahia para que faça expedir sem perda de tempo todas as Pessoas, e ferramentas necessárias para se proceder na construção dos Baluartes, e na reforma dos reparos das Peças; e ao novo Diretor recomendo o maior zelo em todos os ditos trabalhos, para que a dita Fortaleza, e as Vossas Terras fiquem na devida segurança, e podeis ficar certo, que o Diretor que transgrediu as Minhas Ordens, e que não teve atenção com os Vossos Desejos, será punido exemplarmente segundo as Leis, logo que se transportar a estes Reinos

Li com grande sentimento o Parágrafo da Vossa Carta, em que Me dáveis parte das hostilidades, que haviam sido cometidas nessa Carta por parte dos Franceses, e vos agradeço muito toda a atenção, e cuidado, que mostrasteis pela conservação das equipagens Portuguesas; porém como Me consta, que nos Vossos Domínios ficaram cativas, e escravas algumas Pessoas (fl. 2) pertinentes aos meus Vassalos: Espero da Vossa Justiça, e Amizade, que os faceis logo por na sua liberdade, e os entregareis ao Diretor, para que os haja de remeter aos respectivos donos.

Os Vossos Embaixadores se comportaram nesta Corte com toda decência, e honra, próprias do seu caráter; dando-Me todas as provas do seu zelo pelo Vosso Serviço, e fazendo-se dignos da Minha Real Atenção; e portanto merecedores da Vossa particular Benevolência na qual os recomendo.

Eu lhes mandei assistir com tudo aquilo, de que necessitavam para a sua decente subsistência, na forma que vos será constante pela conta que vos transmito, e igualmente lhes mandei satisfazer a sua passagem até a Bahia; ordenando ao governador daquele Estado, que os assista igualmente com todo o necessário até chegarem aos Vossos Domínios.

Fora da Vossa Carta encontrei um Papel sem Assinatura em que Me pedíeis um Bergantim pronto de tudo para a guarda desse Porto; como também um homem que soubesse bem ler, e escrever para ficar convosco; e finalmente pedieis também, que vos enviasse um Navio, cuja carga fosse de sedas boas de ouro, e prata em obra, e tudo os mais que pertence a um Rei, e finalmente quarenta Peças de Bronze, e Ferro bastantemente reforçadas para guarnecer a Vossa Terra; a tudo isto procurarei satisfazer quando Me seja possível logo que as circunstâncias Me permitirem, porque na presente ocasião Me é impossível fazê-lo, 
não só por falta de tempo, mas por outros diferentes (fl. 2v) motivos, de que é supérfluo informar-vos; desejando em tudo comprazer-vos, como cumpre a Minha Fiel Amizade.

Nobre e Honrado Rei de Dagomé. Nosso Senhor vos alumie em sua Santa Guarda. Escrita no Palácio de Queluz aos seis de janeiro de mil setecentos noventa e seis.

Príncipe.

Sobrescrito.

Ao Nobre e Honrado Rei de Dagomé.

João Gomes de Araújo.

O Secretário Francisco Elesbão Pires de Carvalho Albuquerque.

Carta 2: IHGB, DL 137,62

De:(sem nome) rei de Artdra

Para: príncipe d. João, regente de Portugal

Local e data: Ardra, 1810

Transcrição e atualização ortográfica por Mariza de Carvalho Soares

\section{(fl. 1) Fidelíssimo Senhor}

A centos de anos que os povos deste continente tem a honra de comerciarem com as Nobres Nações polidas ficando sempre em dessabor aos Meus Antecessores e presentemente a mim próprio o não poder resgatar os Vassalos de Vossa Alteza Real que se acham prisioneiros com o nome de cativos e tratados como tais do meu vizinho e contrário rei Dagomê.

No seguinte mês depois da minha posse e Coroação fiz expedir um meu embaixador a propor ao dito apesar que me assusta de ouvir dizer aos Meus Antecessores e ser também do meu tempo quer andar falsamente e sem Causas fazendo estragos aos Navios que desprezam o seu Porto e procuram este e outros quaisquer aonde vejam que podem fazer melhor vantagem nas suas fazendas, e a brevidade propondo-lhe também que era muito mal feito o fazer estragos aos Navios e cativar os brancos pois que com ele nunca constou que houvesse Guerra para com as Nações deste País e que visse que os [rasgado] Ingleses, Portugueses, Americanos e Dinamarqueses se continuavam a vir a este Porto e aos outros e desprezavam o seu era pelo mal agasalho que nele recebiam pois que todos os negócios são feitos à vontade e não à força. 
No dia 19 de abril de 1810 chegaram 207 vassalos do dito meu contrário fugidos deixando a sua Pátria vindo sujeitarem-se às Leis do meu Governo e entre eles um com recomendações dos Portugueses que se acham Cativos para me falar ocultamente e pondo ao dito em [epecussão] mandam-se aqueles valerem-se de mim pois que tinham sido Cativos nas minhas Praias pois que o seu Monarca deles se não lembrava e dos grandes castigos que recebem e infinitas misérias.

Condoído eu por conhecer a razão assistia aos desgraçados mandei acertar pelos oito Portugueses que se acham cativos o valor oitenta cativos em moeda corrente dos Nosso País; ou sedas ou ferro; ou escravos pretos; e como tivesse a resposta que os não dava por ser dos brasões do Seu Estado o ter escravos brancos sendo esta a Causa que me move a enviar meu embaixador a Real presença ofertar as Minhas Praias para que nelas queira Vossa Alteza Real mandar Edificar quantas Fortalezas quiser a bem do Comércio e Guerra do Estado e nas mesmas ou interior [rasgado] poderão os caixas ou mestres dos Navios (fl. 1v) estabelecerem quantas Casas de Negócios quiserem sem condição ou tributo algum e poderão comprar Marfim, cera, Pau Brasil, Panos, Azeite de Palmas e Escravos e tudo quanto houver no País, e poderão também plantar Algodão, Café, Anil, Milho, Feijão, Arroz e tudo quanto produzirem as terras não pagando coisa alguma das ditas só sim aos jornaleiros no [caso] que não queiram trabalhar com escravos seus.

Eu tenho por notícia que o capitão Inocêncio Marques de Santa Anna tinha vindo tomar umas medidas no lugar aonde se deve fazer um pequeno Reduto que somente acomoda oito peças e mandando eu saber por ordem de quem tinha vindo às Minhas Praias a tomar medidas e fazer marcações Respondeis-me que o falecido Conde da Ponte por ser Fidalgo de muita curiosidade e saber que ele dito tinha [...] cativo do Dagomê e passava por aquele lugar man[rasgado] ser distância que tinha de Norte e Sul e de Leste ao Oeste igualmente a planta daqueles lugares por ser ele o único prisioneiro que por ali passara e como se acha liberto por este motivo o Obriguei a ordem de Vossa Alteza Real, para que me conduzisse o meu embaixador à cidade da Bahia e desta à cidade e Corte do Rio de Janeiro ficando eu na certeza que Vossa Alteza Real se mandará informar se deve ou não abandonar o Castelo de Ajudá o qual é feito pela terra dentro duas léguas ou deixar de fazer um dito à borda d'água no qual poderão os Caixas ter tudo quanto é negociação para refração das Embarcações bem como acontece aos das mais nações. 
Juntamente lembra-me o ter notícias que dois Diretores do dito Castelo de Ajudá tem sido remetidos para a cidade da Bahia ao depois de serem amarrados e açoitados pelos naturais daquele País, e por muitas vezes tem sido a Bandeira Portuguesa desprezada e igualmente a inglesa.

As posses destes Estados não deixam aos Monarcas mostrarem os seus verdadeiros sentimentos pois em nada posso oferecer para a feitura do Forte que suplico senão serventes, barro, Madeiras, e tudo quanto houver nos Meus Domínios pois desejo ligar, e estabelecer com os Portugueses a mesma Amizade que tem o Rei Congo da cidade de Angola.

He [rasgado] me ofereço a por na Respeitável presença de

(fl. 2) De Vossa Alteza Real desejando que na posse desta goze perfeita saúde e igualmente suas Altezas e toda a Nobre Corte para amparo dos Vassalos. Deus guarde a Vossa Alteza Real por muitos anos pois sou

De Vossa Alteza Real amigo e [obrigado]

O Rey [rasgado] [...]

Carta 3: IHGB, DL 137,62

De: conde dos Arcos, governador da Bahia

Para: conde das Galveas, ministro de assuntos estrangeiros

Local e data: Bahia, 07.05.1811

Transcrição e atualização ortográfica por Flávia Maria de Carvalho

(fl. 1) Rubricado em 28 agosto de 1811

Ilustríssimo Excelentíssimo Senhor

Logo que recebi a Régia Ordem que Vossa Excelência me fez a mercê de dirigir-me em data de seis de fevereiro do presente ano, mandei imediatamente avisar os Embaixadores dos Reis de Ardra ou Porto Novo, e Daomé para que em sua observância viessem tratar diretamente comigo sobre suas respectivas Missões.

Com facilidade se prestou o do Rei de Ardra, o qual logo trouxe, e me apresentou a Carta que vai em primeiro lugar junta, não o imitando o do Daomé porque insistia em querer ir a essa Corte por isso que assim era Ordem do seu Rei.

Tendo-lhe porém eu dito firme, e secamente que as Ordens de Sua Alteza Real eram as que regiam neste caso, depois de breve consulta com os seus companheiros de embaixada, resolveu-se a entregar-me o Saco em que vinham os ridículos, e abomináveis escritos em segundo lugar juntos. 
Escrever sobre as matérias que contém nestes escritos é no meu modo de pensar a maior das temeridades enquanto este Governo não tem outros dados mais em que se funde se não os ditos dos Mestres de Navios da (fl. 1v) Costa, que são os Indivíduos mais bárbaros da espécie humana, e outras Cartas destes mesmos Potentados remetidas em outro tempo a meus Antecessores.

Desprovido portanto de quaisquer fundamentos que me deem confiança na minha mesma opinião sobre tal matéria, e reconhecendo de outra parte que se trata contudo entre montões de objetos frívolos, e [feroces] de negócios úteis a Religião e ao Estado não pode ser outro o meu parecer se não que primeiro que tudo se trate de obter os conhecimentos sólidos, e necessários para entrar com claridade nesta matéria, mandando pessoas de inteligência, e probidade aos Portos de ambos os Potentados encarregados de transmitir ao Governo com a maior exatidão todas as ideias sobre a História, Topografia, interesses econômicos, e parte Militar dos dois países sem as quais confesso a Vossa Excelência que não me atrevo a falar na Augusta Presença de Sua Alteza Real sobre este negócio: o que tanto mais terá lugar, não sendo novo temporizar com estes Potentados como se mostra na Cópia junta da carta assinada pelo Régio Punho datada aos seis (fl. 2) de janeiro de 1796.

Se por ventura esta minha opinião merecer o Real Beneplácito e for ainda agradável a Sua Alteza Real que eu interponha para o futuro meu parecer sobre esta matéria, peço instantissimamente a Vossa Excelência alguma explicação que me aclare a inteligência do Artigo Décimo do Tratado de Aliança de 19 de Fevereiro de 1810, sendo igualmente indispensável para que eu fale sisudamente sobre este negócio estar certo se a Suprema Vontade de Sua Alteza Real é adotar os mais eficazes meios para conseguir em toda a extensão dos seus domínios uma gradual abolição do Comércio de Escravos, ou que as estipulações daquele mesmo artigo não sejam consideradas como limitando ou restringindo o Comércio de Ajudá.

Não ajunto Cópias das outras Cartas destes Potentados dirigidas a meus Predecessores porque elas tratam de objetos que não tem a mais remota analogia com os de que agora se faz menção; constando-me que a primeira vez que aqui vieram Emissários dos Reis Africanos foram em 1750 quando era (fl. 2v) Vice-Rei deste Estado o Conde de Athouguia sendo o objeto de sua Missão o pedir continuação do Comércio; que a segunda fora em 1795 sendo Governador desta Capitania o Senhor Conde 
de Aguiar pretendendo naquela ocasião o Rei Daomé o Comércio exclusivo sobre que aquele Governador escreveu seu Ofício de 21 de outubro do mesmo ano com a discrição que lhe é própria; e a terceira em 1805 governando esta Capitania Francisco da Cunha e Menezes tendo aquela Missão por objetos primo, instar sobre a pretensão de 1795.

Segundo, intentar a exploração de Minas de Ouro, e Tértio propor a abolição da Diretoria de Ajudá; o que me parece não prestar qualquer auxílio a inteligência e decisão dos negócios que presentemente se propõem.

Deus Guarde a Vossa Excelência Bahia 7 de Maio de 1811. Ilustríssimo e Excelentíssimo Senhor Conde das Galvêas

Conde dos Arcos.

Carta 4: BN-RJ - II-33-29-23

De: conde das Galveas, ministro de assuntos estrangeiros

Para: conde do Arcos, governador da Bahia

Local e data: Palácio do Rio de Janeiro, 02.08.1811

Transcrição e atualização ortográfica por Flávia Maria de Carvalho

(fl. 1) Ofício do conde de Galveas ao conde dos Arcos, governador da Bahia, 1811.

Subiu a Augusta Presença de Sua Alteza Real o Príncipe Regente Nosso Senhor o Ofício de Vossa Excelência, datado de 7 de maio do corrente ano, e com ele as cartas que os reis de Ardra e de Daomé dirigiram a Sua Alteza Real pelos Embaixadores, que aí se acham, as quais são com efeito mui notáveis, como Vossa Excelência observa, e tais quais se podiam esperar de semelhantes Potentados.

Por elas todavia se reconhece, que as precauções ao rei de Daomé se acham em completa oposição com as do Rei de Ardra, por isso que o primeiro pretende que o nosso comércio se torne exclusivo aos seus Portos, enquanto que o segundo facilita e oferece o seu, mediante toda qualidade de cooperação da sua parte, para o tornar mais vantajoso e seguro, e é provável que desta oposição resultem as queixas e investidas, que se fazem mutuamente estes dois régulos, em cujas questões não quer Sua Alteza Real entrar de modo algum; limitando-se simplesmente ao caso de pôr ao claro a conduta e procedimento do rei de Daomé contra alguns vassalos portugueses, de que o acusa o de Ardra, o que ele de modo algum não nega, posto que quer cortar este fator como praticados com sujeitos pertencentes ao partido do seu inimigo, e sobre este objeto comum, que, indicasse as 
nações que Vossa Excelência possa coligir haja Vossa Excelência de fazer as necessárias intimações aos respectivos Embaixadores.

Passando porém a tratar do prosseguimento que Vossa Excelência de dar ao Trato do Negócio de tais Embaixadas, para que represento Vossa Excelência, que começava por necessitar de maior elucidação sobre a verdadeira inteligência do Artigo X do Tratado de Aliança de 19 de fevereiro de 1810, concluído com a Grã-Bretanha, isso mesmo que Vossa Excelência hesitava sobre as intenções que se tivessem de seguir uma gradual abolição do comércio de escravatura, o que não podia deixar de ser impolítico nas nossas atuais circunstâncias, não deixei de me dirigir ao Ministro e Secretário de Estado dos Negócios Estrangeiros e da Guerra, Conde de Linhares, como havendo sido o Negociador daquele tratado a fim de que sobre o Artigo em questão me transmitisse todas aquelas declarações, com que Vossa Excelência, desejava ser assinado, ainda que era óbvio da letra do referido artigo; que nosso tráfico de escravatura deveria continuar não só naqueles portos, pertencentes ao Domínio se Sua Alteza Real, e naqueles que a que se julgasse com direito a Sua Coroa, mas ainda em todos os mais em que os seus vassalos se achassem em posse de fazer aquele comércio. E transmitindo a Vossa Excelência a cópia da resposta que me deu o mencionado Secretário de Estado, em que confirma esta mesma interferência, devo acrescentar a Vossa Excelência, por ordem de Sua Alteza Real, a declaração de que, longe de ser da sua Real Intenção restringir de qualquer modo semelhante comércio, o Mesmo Senhor se propõem a promove-lo e facilitá-lo, quanto se possa, bem convencido da necessidade que há, de lançar mão deste único recurso, que temos, de aumentar a população deste vasto continente, onde há tão sensível falta de braços, que Vossa Excelência conhece, não só para a agricultura, mas para toda a qualidade de trabalhos.

Debaixo destes princípios poderá Vossa Excelência regular aquelas negociações, sendo certo que não podem ser admitidas as restrições e Monopólio, que pretende o Rei de Daomé, por serem tais pretensões expressamente contrárias ao sistema e princípios liberdade de Comércio, que Sua Alteza Real tem mandado adotar em tão reconhecida vantagem aos Seus Fiéis Vassalos.

Enquanto aos reconhecimentos sobre o local daqueles países e mais nações, sobre que Vossa Excelência diz, que serão necessários exames, julgou Sua Alteza Real que seria a propósito, que Vossa Excelência mandasse proceder a eles por algum daqueles indivíduos que frequentam 
os mesmos Portos, encarregando Vossa Excelência esta diligência aos que parecem mais capazes de a desempenharem, ou por qualquer outro modo, que o zelo e judicioso discernimento de Vossa Excelência lhe ditarem, não sendo entretanto mui difícil de espaçar e temporizar com os Emissários, enquanto se lhes não dá uma decisiva resposta, e Sua Alteza Real não remete daqui as Cartas que eles devem levar aos Seus Reis. O que participo a Vossa Excelência para sua inteligência.

Deus Guarde a Vossa Excelência.

[Conselheiro Negócios Estrangeiros]

Palácio do Rio de Janeiro, 2 de agosto de 1811.

Conde das Galveas.

Senhor Conde dos Arcos.

Carta 5: BN-RJ - II-33,29,127

De: conde das Galveas, ministro de assuntos estrangeiros

Para: conde dos Arcos, governador da Bahia

Local e data: Palácio do Rio de Janeiro, 21.03.1812

Transcrição e atualização ortográfica por Flávia Maria de Carvalho

(fl. 1) ilustríssimo Excelentíssimo Senhor

Acuso a recepção do ofício que Vossa Excelência me dirigiu em data de 24 de fevereiro do corrente ano sobre os embaixadores Pretos que se acham ainda nessa cidade, e que conviria fazer retirar para a sua Pátria com a brevidade possível, e tendo levado a presença de Sua Alteza Real Nosso Senhor aprova o mesmo senhor que Vossa Excelência assim o pratique pela maneira que for mais conveniente e própria em tais ocasiões: e havendo já Sua Alteza Real mandado dar de presente ao chefe daquela embaixada uma bandeja de um aparelho completo de chá, ordena que Vossa Excelência quando julgue a propósito a bem do tráfico e relações que temos com os territórios donde lhe vieram, e sendo essa a prática que aí se tem seguido em semelhantes ocorrências, mimosear os mesmos Embaixadores o faça, regulando-se em tal caso via devida proporção do presente que se Sua Alteza Real lhes mandou dar, e conciliando a conveniente e necessária decência que se deve guardar a semelhante respeito com as atuais exigências ao Estado.

Deus Guarde a Vossa Excelência.

Palácio do Rio de Janeiro em 21 de Março de 1812.

Conde de Galveas

Conde dos Arcos

270 Afro-Ásia, 49 (2014), 229-271 
Texto recebido em 11 de julho de 2013 e aprovado em 25 de novembro de 2013

\title{
Resumo
}

$\mathrm{O}$ artigo trata da correspondência entre o rei de Portugal e os reis africanos da Costa dos Escravos entre 1910 e 1812. Esses anos correspondem à assinatura de dois importantes tratados com a Grã-Bretanha envolvendo a extinção do tráfico atlântico de escravos. O artigo recupera a análise da historiadora brasileira Ângela de Castro Gomes sobre as correspondências interpessoais como gênero literário para explorar cartas de Adandozan (rei do Daomé) e d. João (na época, regente de Portugal). Essa correspondência mostra um d. João apegado à diplomacia e às diretrizes estabelecidas por seus antepassados, trazendo à tona seus compromissos políticos com a escravidão.

Palavras-chave: tráfico atlântico de escravos - diplomacia - Brasil - Daomé cartas

\begin{abstract}
The article analyses the correspondence between the Portuguese and Slave Coast African kings between 1810 and 1812. Those years cover the signing of two important treaties with Great Britain involving the abolition of the transatlantic slave trade. The paper brings to scene the Brazilian historian Angela Castro Gomes' analysis about personal correspondences as a literary genre to explore the letters of Adandozan, the king of Dahomey, and Dom João, at that time, regent of Portugal. This correspondence presents Dom João as a man attached to the early Portuguese diplomacy of his ancestors, bringing out his political commitment with slavery.
\end{abstract}

Keywords: transatlantic slave trade - diplomacy - Brazil - Dahomey - letters 